\title{
Estrogen Receptor Beta (ER $\beta)$ Maintains Mitochondrial Network Regulating Invasiveness in an Obesity-Related Inflammation Condition in Breast Cancer
}

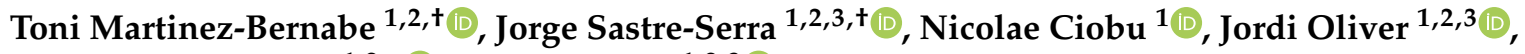 \\ Daniel Gabriel Pons 1,2,*(D) and Pilar Roca 1,2,3
}

1 Grupo Multidisciplinar de Oncología Traslacional, Institut Universitari d'Investigació en Ciències de la Salut (IUNICS), Universitat de les Illes Balears, 07122 Palma de Mallorca, Illes Balears, Spain; toni.martinez@uib.es (T.M.-B.); jorge.sastre@uib.es (J.S.-S.); nicusorciobu@gmail.com (N.C.); jordi.oliver@uib.es (J.O.); pilar.roca@uib.es (P.R.)

2 Instituto de Investigación Sanitaria de las Islas Baleares (IdISBa), Hospital Universitario Son Espases, Edificio S, 07120 Palma de Mallorca, Illes Balears, Spain

3 Ciber Fisiopatología Obesidad y Nutrición (CB06/03), Instituto Salud Carlos III, 28029 Madrid, Madrid, Spain

* Correspondence: d.pons@uib.es; Tel.: +34-9711-73149

+ These authors contributed equally to this work.

Citation: Martinez-Bernabe, T.; Sastre-Serra, J.; Ciobu, N.; Oliver, J.; Pons, D.G.; Roca, P. Estrogen Receptor Beta $(E R \beta)$ Maintains Mitochondrial Network Regulating Invasiveness in an Obesity-Related Inflammation Condition in Breast Cancer. Antioxidants 2021, 10, 1371. https://doi.org/10.3390/ antiox10091371

Academic Editors: Chiara Nediani and Monica Dinu

Received: 30 July 2021

Accepted: 24 August 2021

Published: 28 August 2021

Publisher's Note: MDPI stays neutral with regard to jurisdictional claims in published maps and institutional affiliations.

Copyright: (c) 2021 by the authors. Licensee MDPI, Basel, Switzerland. This article is an open access article distributed under the terms and conditions of the Creative Commons Attribution (CC BY) license (https:/ / creativecommons.org/licenses/by/ $4.0 /)$.

\begin{abstract}
Obesity, a physiological situation where different proinflammatory cytokines and hormones are secreted, is a major risk factor for breast cancer. Mitochondrial functionality exhibits a relevant role in the tumorigenic potential of a cancer cell. In the present study, it has been examined the influence of an obesity-related inflammation ELIT treatment (17 $\beta$-estradiol, leptin, IL-6, and $\mathrm{TNF} \alpha$ ), which aims to stimulate the hormonal conditions of a postmenopausal obese woman on the mitochondrial functionality and invasiveness of MCF7 and T47D breast cancer cell lines, which display a different ratio of both estrogen receptor isoforms, ER $\alpha$ and $E R \beta$. The results showed a decrease in mitochondrial functionality, with an increase in oxidative stress and invasiveness and motility, in the MCF7 cell line (high ER $\alpha / E R \beta$ ratio) compared to a maintained status in the T47D cell line (low $\mathrm{ER} \alpha / \mathrm{ER} \beta$ ratio) after ELIT treatment. In addition, breast cancer biopsies were analyzed, showing that breast tumors of obese patients present a high positive correlation between IL- 6 receptor and ER $\beta$ and have an increased expression of cytokines, antioxidant enzymes, and mitochondrial biogenesis and dynamics genes. Altogether, giving special importance to ER $\beta$ in the pathology of obese patients with breast cancer is necessary, approaching to personalized medicine.
\end{abstract}

Keywords: obesity-related inflammation; oxidative stress; mitochondrial biogenesis; mitochondrial dynamics; epithelial-to-mesenchymal transition (EMT); estrogen receptor beta (ER $\beta$ ); breast cancer

\section{Introduction}

Cancer, a pathology characterized by the excessive proliferation of tumor cells, is the second cause of death in the world, responsible for approximately 9.6 million deaths in 2018. In addition, breast cancer is a disease causing more than half a million deaths annually, projecting an increase in its incidence to a total of 3.2 million new cases per year in 2050 [1,2]. Breast cancer is a heterogeneous and multifactorial disease that involves both genetic predisposition, lifestyle, and environmental factors. In fact, it has been estimated that about $20 \%$ of breast cancer cases around the world are attributed to modifiable risk factors, which include obesity [1].

Obesity is a chronic metabolic disease characterized by excess fat accumulation in the body, and its prevalence has increased markedly in the last two decades in the most developed countries [3]. In obesity conditions, there is an alteration of the adipocyte secretome, which can lead to an imbalance of secreted adipokines, affecting processes as cell proliferation, invasive growth, apoptosis, angiogenesis, and metastasis in tumor cells 
of tissues such as the mammary gland [4-6]. Obesity is a risk factor for breast cancer due to increased circulating estrogens, such as $17 \beta$-estradiol. This is explained by the high conversion rate of the androgenic precursors produced by aromatase, an enzyme that increases its activity in the obese state [7].

The cellular effects of estrogens are mediated by their binding to estrogen receptors (ER) alpha $(E R \alpha)$, beta(ER $\beta)$, and GPER. Although ER $\alpha$ and ER $\beta$ show homology in the DNA and ligand-binding domains, their activity and affinity for $17 \beta$-estradiol are different, with $E R \alpha$ having a higher affinity for it. In addition, the expression pattern of the receptors also varies according to the cell type [8-10]. ER $\alpha$ is postulated as the main mediator of the carcinogenic effects of $17 \beta$-estradiol in breast cancer. In the case of $E R \beta$, which is less studied, it is associated with an antiproliferative, cytostatic, and protective effect against tumor development, although other studies have observed contrary results, so its role in breast cancer remains to be clarified [10-12]. Secondly, GPER, also known as GPR30, is a G protein-coupled receptor that can be activated by estrogen to induce effects on proliferation, migration, and invasion, particularly in breast cancer [13].

Another adipokine synthesized and secreted by adipocytes is leptin, whose circulating levels are directly correlated with the individual's BMI [14]. Leptin has an important role as an independent predictor of risk and prognosis of breast cancer, which has been correlated with its circulating levels. Thus, women with breast cancer have higher plasma leptin levels and RNA expression in adipose tissue than healthy subjects [5,7]. Leptin exerts its biological role by binding to the leptin receptor, which is expressed in normal mammary epithelial cells and breast cancer cell lines, observing an effect on the stimulation of proliferation, cell division, invasion, and metastasis, through the JAK2/STAT3, MAPKs and PI3K/Akt signaling pathways. Furthermore, leptin is also capable of enhancing aromatase expression and activity [11], resulting in increased circulating levels of estrogens, which in turn have been shown to increase mRNA expression and leptin secretion from adipose tissue [14].

It is worth noting that obesity is considered an inducing factor of inflammation, where adipose tissue takes on the role of producer of cytokines and inflammatory proteins. However, the biochemical role between inflammation and cancer-inducing cellular modifications has not yet been elucidated [12]. In this way, the adipose tissue adjacent to the breast tissue is essential in the progression of cancer for the production of proinflammatory cytokines, leptin, and $17 \beta$-estradiol $[15,16]$.

The expression of inflammatory cytokines, such as interleukin-6 (IL6) and Tumor necrosis factor alpha $(\mathrm{TNF} \alpha)$, have been related to an increase in invasiveness and a poor prognosis in breast cancer [16]. IL6 is secreted by macrophages, fibroblasts, synovial cells, endothelial cells, and keratinocytes, but it is also synthesized by adipocytes $[16,17]$. Through the interaction with its receptor, IL6 would be able to induce aromatase, inducing a greater synthesis of $17 \beta$-estradiol [17]. On the other hand, TNF $\alpha$ is a key inflammatory cytokine produced by macrophages, T cells, B cells, and NK cells, in addition to tumor cells [14]. As a major cytokine in the tumor microenvironment, TNF $\alpha$ influences several of the hallmarks of cancer, such as stimulation of tumor growth, survival, invasion, metastasis, and angiogenesis $[18,19]$. In breast cancer cell lines, TNF $\alpha$ may have a role in both promoting and inhibiting cell growth, suggesting that the signaling pathway through which it contributes to proliferation is MAPK and PI3K/Akt [5].

Mitochondria is a cellular organelle that is highly influenced in response to estrogens, and it is the main source of reactive oxygen species (ROS), playing an important role in tumor processes, as well as in proliferation and apoptosis [20-22]. There is a balance between the production of ROS in the cell and its detoxification by antioxidant enzymes. If antioxidant mechanisms are diminished or ROS production undergoes a significant increase, an imbalance occurs in this system that leads to oxidative damage [23].

Mitochondrial function depends on mitochondria morphology, changes in shape, number, and location, which can translate into important functional modifications. Thus, mitochondrial biogenesis is the combination of both proliferation (an increase in the mitochondrial population) and differentiation (an improvement of the functional capabilities of 
pre-existing mitochondria) processes [24], while mitochondrial dynamics is a concept that describes the morphology and distribution of mitochondria in the cell [25].

Mitochondrial structure and function can be regulated by the activation of ER $\alpha$ and $E R \beta$ receptors by binding of $17 \beta$-estradiol $[6,26]$. Regarding the role of $E R \beta$, some studies have implicated it as a tumor suppressor in breast cancer [6]. ER $\beta$ has been shown to colocalize in the mitochondria $(\mathrm{mtER} \beta)$ and mediate estrogenic effects on the mitochondria, being able to increase mtDNA, increase respiratory capacity, increase antioxidant activity, and inhibit apoptosis [8].

Dysfunctional mitochondria play a relevant role in cancer and in the epithelial-tomesenchymal transition (EMT) program in breast cancer [27]. As a consequence of mitochondrial defects, deteriorated OXPHOS has been shown to be involved in tumorigenesis [27]. In fact, alteration of mitochondrial functionality has been correlated with a specific mesenchymal phenotype. Moreover, previous studies have hypothesized a link between the regulation of mitochondrial genes, induction of EMT, and metastasis, which implies the worst clinical outcome for patients with cancer [28]. As mentioned above, obesity is an inflammatory disorder in which adipokines, as resistin or leptin, are secreted and play an important role in EMT. It has been described that obesity promotes the metastatic potential of breast cancer by inducing EMT [29]. Moreover, leptin promotes diverse biological events associated with tumorigenesis, as EMT. This process is induced by leptin through the expression of diverse transcription factors, which repress the epithelial markers and promote mesenchymal markers [30].

The aim of the present work was to study mitochondrial functionality and invasiveness, analyzing mitochondrial biogenesis and dynamics processes, as well as oxidative stress and inflammatory status and motility, in cell lines with different estrogen receptors ratio, exposed to a treatment consisting of $17 \beta$-estradiol, leptin, IL-6, and TNF $\alpha$ simulating circulating hormonal conditions in a postmenopausal obese woman [31-33] Likewise, the expression of the main antioxidant genes and genes related to inflammation and mitochondrial functionality in breast cancer tumors have been studied.

\section{Materials and Methods}

\subsection{Reagents}

Specific reagents $17 \beta$-estradiol, leptin, interleukin-6, and TNF- $\alpha$ were purchased from Sigma-Aldrich (St. Louis, MO, USA). Dulbecco's modified Eagle's medium without phenol red was purchased from GIBCO (Paisley, UK), Fetal Bovine Serum, and antibiotics solution (penicillin and streptomycin) from Biological Industries (Kibbutz Beit Haemek, Israel). Routine chemicals were supplied by Sigma-Aldrich (St. Louis, MO, USA), Panreac (Barcelona, Spain), and Bio-Rad Laboratories (Hercules, CA, USA).

\subsection{Cell Culture and Treatments}

MCF7 and T47D breast cancer cell lines were purchased from American Type Culture Collection ATCC (Manassas, VA, USA) and maintained in Dulbecco's modified Eagle's medium (DMEM) supplemented with $10 \%$ Foetal bovine serum (FBS) and $1 \%$ antibiotics (penicillin and streptomycin) at $37{ }^{\circ} \mathrm{C}$ with $5 \% \mathrm{CO}_{2}$. To avoid phenol red estrogenic effect, cells were seeded in 6-well or 96-well plates in phenol red-free DMEM containing 10\% FBS and $1 \%$ antibiotics $24 \mathrm{~h}$ prior to treatment. Cells were treated, at $70-80 \%$ confluence, with vehicle (0.1\% DMSO) or ELIT treatment ( $10 \mathrm{nM} 17 \beta$-estradiol, $100 \mathrm{ng} / \mathrm{mL}$ leptin, $50 \mathrm{ng} / \mathrm{mL}$ interleukin- 6 and $10 \mathrm{ng} / \mathrm{mL} \mathrm{TNF} \alpha$ ) for 24 or $48 \mathrm{~h}$.

\subsection{Measurement of $\mathrm{H}_{2} \mathrm{O}_{2}$ Production and $\mathrm{O}_{2}{ }^{-}$Levels}

Cells were seeded in 96-well plates $\left(1.6 \times 10^{4}\right.$ cells $/$ well for MCF7 and $3.2 \times 10^{4}$ cells /well for T47D cell line) and treated with ELIT for $48 \mathrm{~h}$. Hydrogen peroxide production was determined by Amplex ${ }^{\circledR}$ Red Hydrogen Peroxide/Peroxidase Assay Kit, following the manufacturer's protocol, as described previously [34]. Superoxide anion levels were determined by MitoSOX ${ }^{\circledR}$ Red reagent, following the manufacturer's protocol, as described 
previously [35]. The values obtained were normalized with the Hoechst 33342 fluorescence signal as previously described [36].

\subsection{Cardiolipin Content}

Cells were seeded in 96-well plates $\left(1.6 \times 10^{4}\right.$ cells $/$ well for MCF7 and $3.2 \times 10^{4}$ cells /well for T47D cell line) and treated with ELIT for $48 \mathrm{~h}$. Cells were stained with $250 \mathrm{nM}$ of Nonyl Acridine Orange (NAO) to measure cardiolipin content as previously described [26]. The values obtained were normalized with the Hoechst 33342 fluorescence signal, as previously described [36].

\section{5. $R T-q P C R$}

Cells were seeded $\left(4 \times 10^{5}\right.$ cells / well for MCF7 and $6 \times 10^{5}$ cells/well for T47D cell line) in 6-well plates and treated with ELIT for $24 \mathrm{~h}$. Total RNA from cultured cells or breast cancer human biopsies ( $25 \mathrm{mg}$ ) was isolated using TRI Reagent (Sigma-Aldrich, St. Louis, $\mathrm{MO}$, USA), following the manufacturer's protocol, and then quantified using a BioSpecnano spectrophotometer (Shimadzu Biotech, Kyoto, Japan) set at $260 \mathrm{~nm}$ and $280 \mathrm{~nm}$, getting 260/280 nm ratio. Samples were retrotranscribed to cDNA, and PCR reactions were carried out as previously reported [35]. Genes, primers, and temperatures for the annealing step are specified in Table 1. Both GAPDH and $18 \mathrm{~S}$ were used as housekeeping genes.

Table 1. Primers and conditions used for RT-qPCR.

\begin{tabular}{|c|c|c|}
\hline \multirow{2}{*}{$\begin{array}{c}\text { Gene } \\
\text { Accession Number }\end{array}$} & Forward Primer $\left(5^{\prime}-3^{\prime}\right)$ & \multirow{2}{*}{ An. $\mathrm{T}^{\circ}\left({ }^{\circ} \mathrm{C}\right)$} \\
\hline & Reverse Primer $\left(5^{\prime}-3^{\prime}\right)$ & \\
\hline ESR2 & TAG TGG TCC ATC GCC AGT TAT & \multirow{2}{*}{60} \\
\hline NM_001437.3 & GGG AGC CAC ACT TCA CCA T & \\
\hline NFE2L2 & GCG ACG GAA AGA AGT ATG AGC & \multirow{2}{*}{60} \\
\hline NM_006164.5 & GTT GGC AGA TCC ACT GGT TT & \\
\hline CAT & CAT CGC CAC ATG AAT GGA TA & \multirow{2}{*}{61} \\
\hline NM_001752.4 & CCA ACT GGG ATG AGA GGG TA & \\
\hline GSR & TCA CGC AGT TAC CAA AAG GA & \multirow{2}{*}{64} \\
\hline NM_000637.5 & CAC ACC CAA GTC CCC TGC AT & \\
\hline SOD1 & TCA GGA GAC CAT TGC ATC ATT & \multirow{2}{*}{64} \\
\hline NM_000454.5 & CGC TTT CCT GTC TTT GTA CTT TCT TC & \\
\hline SOD2 & CGT GCT CCC ACA CAT CAA TC & \multirow[b]{2}{*}{64} \\
\hline NM_000636.4 & TGA ACG TCA CCG AGG AGA AG & \\
\hline UCP2 & GGT GGT CGG AGA TAC CAA & \multirow[b]{2}{*}{60} \\
\hline NM_001381943.1 & CTC GGG CAA TGG TCT TGT & \\
\hline$T N F$ & AAG CCT GTA GCC CAT GTT GT & \multirow[b]{2}{*}{58} \\
\hline NM_000594.4 & GGA CCT GGG AGT AGA TGA GGT & \\
\hline \multirow{2}{*}{$\begin{array}{c}\text { PTGS2 } \\
\text { NM_000963.4 }\end{array}$} & CCC TTC TGC CTG ACA CCT TT & \multirow{2}{*}{60} \\
\hline & TTC TGT ACT GCG GGT GGA AC & \\
\hline IL6 & CAG GGG TGG TTA TTG CAT CT & \multirow{2}{*}{60} \\
\hline NM_000600.5 & AGG AGA CTT GCC TGG TGA AA & \\
\hline CXCL8 & GGC ACA AAC TTT CAG AGA CAG CAG & \multirow{2}{*}{66} \\
\hline NM_000584.4 & GTT TCT TCC TGG CTC TTG TCC TAG & \\
\hline IL6R & TGG GAG GTG GAG AAG AGA GA & \multirow{2}{*}{60} \\
\hline NM_000565.4 & AGG ACC TCA GGT GAG AAG CA & \\
\hline CXCR8 & AGT TCT TGG CAC GTC ATC GT & \multirow{2}{*}{58} \\
\hline NM_000634.3 & CCC CTG AAG ACA CCA GTT CC & \\
\hline TGFB & TCC TGG CGA TAC CTC AGC AA & \multirow{2}{*}{60} \\
\hline NM_000660.7 & CGG TAG TGA ACC CGT TGA TG & \\
\hline
\end{tabular}


Table 1. Cont.

\begin{tabular}{|c|c|c|}
\hline \multirow{2}{*}{$\begin{array}{c}\text { Gene } \\
\text { Accession Number }\end{array}$} & Forward Primer $\left(5^{\prime}-3^{\prime}\right)$ & \multirow{2}{*}{ An. $\mathrm{T}^{\circ}\left({ }^{\circ} \mathrm{C}\right)$} \\
\hline & Reverse Primer $\left(5^{\prime}-3^{\prime}\right)$ & \\
\hline NRF1 & CCA CGT TAC AGG GAG GTG AG & \multirow[b]{2}{*}{60} \\
\hline NM_005011.5 & TGT AGC TCC CTG CTG CAT CT & \\
\hline SSBP1 & TGT GAA AAA GGG GTC TCG AA & \multirow{2}{*}{60} \\
\hline NM_001256510.1 & TGG CCA AAG AAG AAT CAT CC & \\
\hline PPARGC1A & TCA GTC CTC ACT GGT GGA CA & \multirow[b]{2}{*}{60} \\
\hline NM_001330751.2 & TGC TTC GTC GTC AAA AAC AG & \\
\hline TFAM & GTG GTT TTC ATC TGT CTT GGC & \multirow{2}{*}{60} \\
\hline NM_003201.3 & ACT CCG CCC TAT AAG CAT CTT & \\
\hline TWNK & GGG AGG AGG TGC TAG GAG AA & \multirow[b]{2}{*}{61} \\
\hline NM_021830.5 & TTC CTG GCT TGC TTT GGC T & \\
\hline MFN1 & TTC GAT CAA GTT CCG GAT TC & \multirow{2}{*}{51} \\
\hline NM_033540.3 & TTG GAG CGG AGA CTT AGC AT & \\
\hline MFN2 & GCA GAA CTT TGT CCC AGA GC & \multirow{2}{*}{56} \\
\hline NM_014874.4 & AGA GGC ATC AGT GAG GTG CT & \\
\hline OPA1 & ACA ATG TCA GGC ACA ATC CA & \multirow[b]{2}{*}{51} \\
\hline NM_015560.3 & GGC CAG CAA GAT TAG CTA CG & \\
\hline OMA1 & TTG GAT TGC TCT TTG TGG TG & \multirow{2}{*}{51} \\
\hline NM_145243.5 & GGT ATC GGG CAT CTT TCT CA & \\
\hline DNM1L & GTT CAC GGC ATG ACC TTT TT & \multirow[b]{2}{*}{51} \\
\hline NM_012062.5 & AAG AAC CAA CCA CAG GCA AC & \\
\hline FIS1 & GCT GAA GGA CGA ATC TCA & \multirow{2}{*}{55} \\
\hline NM_016068.3 & CTT GCT GTG TCC AAG TCC AA & \\
\hline SIRT1 & GCA GAT TAG TAG GCG GCT TG & \multirow{2}{*}{60} \\
\hline NM_012238.5 & TCT GGC ATG TCC CAC TAT CA & \\
\hline SIRT3 & CGG CTC TAC ACG CAG AAC ATC & \multirow{2}{*}{56} \\
\hline NM_012239.6 & CAG AGG CTC CCC AAA GAA CAC & \\
\hline GAPDH & CСA CTC CTC CAC CTT TGA CG & \multirow{2}{*}{60} \\
\hline NM_002046.7 & CTG GTG GTC CAG GGG TCT TA & \\
\hline $18 S$ & GGACACGGACAGGATTGACA & \multirow{2}{*}{60} \\
\hline$N R \_146119.1$ & ACCCACGGAATCGAGAAAGA & \\
\hline STAT3 & CTG GCC TTT GGT GTT GAA AT & \multirow{2}{*}{61} \\
\hline NM_139276.3 & AAG GCA CCC ACA GAA ACA AC & \\
\hline SLC25A14 & CAA GCC GTT GGT CTC CTA AG & \multirow{2}{*}{60} \\
\hline NM_001282195.2 & CGT TTT CAA TGT CAC CCA TC & \\
\hline $\mathrm{CDH1}$ & GTCACTGACACCAACGATAATCCT & \multirow{2}{*}{60} \\
\hline NM_004360.5 & TTTCAGTGTGGTGATTACGACGTTA & \\
\hline ESRRA & TCG CTC CTC CTC TCA TCA TT & \multirow{2}{*}{52} \\
\hline NM_004451.5 & TGG CCA AAC CCA AAA ATA AA & \\
\hline PPARG & GAG CCC AAG TTT GAG TTT GC & \multirow{2}{*}{61} \\
\hline NM_138712.5 & CTG TGA GGA CTC AGG GTG GT & \\
\hline ESR1 & AAT TCA GAT AAT CGA CGC CAG & 61 \\
\hline NM_000125.4 & GTG TTT CAA CAT TCT CCC TCC TG & 61 \\
\hline MMP9 & CGC AGA CAT CGT CAT CCA GT & \\
\hline NM_004994.3 & AAA CCG AGT TGG AAC CAC GA & 60 \\
\hline GPER1 & CAT CAT CGG CCT GTG CTA CT & \\
\hline NM_001505.3 & GAT GAA GAC CTT CTC CGG CA & 60 \\
\hline GPX1 & GCG GCG GCC CAG TCG GTG TA & \\
\hline NM_000581.4 & GAG CTT GGG GTC GGT CAT AA & 61 \\
\hline
\end{tabular}




\subsection{Western Blot}

After $48 \mathrm{~h}$ of ELIT treatment, cells were harvested as described previously by TorrensMas [35]. Protein content (supernatant) was determined with the bicinchoninic acid (BCA) protein assay kit (Thermo Fisher Scientific, Waltham, MA, USA). Ten micrograms of protein were resolved on a 12\% SDS-PAGE gel and electrotransferred onto nitrocellulose membranes using the Trans-blot ${ }^{\circledR}$ Turbo $^{\text {TM }}$ transfer system (Bio-Rad, Hercules, CA, USA). Membranes were blocked in 5\% non-fat powdered milk in TBS with $0.05 \%$ Tween for $1 \mathrm{~h}$. Antisera against OXPHOS complexes (ab110411; Abcam, Bristol, UK), SOD-1 (574597, Calbiochem ${ }^{\circledR}$, San Diego, CA, USA), SOD-2 (sc-30080; Santa Cruz Biotechnology, Santa Cruz, CA, USA), CAT (219010, Calbiochem ${ }^{\circledR}$, San Diego, CA, USA), GRd (sc-133245; Santa Cruz Biotechnology, Santa Cruz, CA, USA), 4-HNE (HNE11-S, Alpha Diagnostic, San Antonio, TX, USA), COXIV (ab33985, Abcam, Bristol, UK), PGC1 $\alpha$ (ab54481, Abcam, Bristol, UK), and GAPDH (sc-25778; Santa Cruz Biotechnology, Santa Cruz, CA, USA) were used as primary antibodies. Protein bands were visualized as described previously by [34].

\subsection{Measurement of 4-HNE Adducts Levels}

For 4-hydroxy-2-nonenal (4-HNE) adducts analysis, as lipid oxidative damage marker, $20 \mu \mathrm{g}$ of total protein from cell lysate, processed as previously described by Pons et al. [37].

\subsection{Wound Healing Assay}

Cells were seeded in six-well plates at a density of $1 \times 10^{6}$ cells/well for T47D cell line and $8.5 \times 10^{5}$ cells/well for MCF7 cell line. Wound healing assay was performed as previously described by Torrens-Mas et al. [35]. The area of the scratch was measured using the MRI Wound Healing Tool macro for ImageJ software.

\subsection{Confocal Microscopy}

Cells were seeded on a glass coverslip inside 6-well plates at a density of $2 \times 10^{5}$ cells/well for MCF7 and $5 \times 10^{5}$ cells/well for T47D. After $24 \mathrm{~h}$, cells were treated with ELIT treatment for $24 \mathrm{~h}$. Then, cells were incubated with MitoTracker ${ }^{\mathrm{TM}}$ Green $0.5 \mu \mathrm{M}$ (Invitrogen, M7514) for $1 \mathrm{~h}$ and LysoTracker ${ }^{\mathrm{TM}}$ Red $0.5 \mu \mathrm{M}$ (L7528, Invitrogen, Waltham, MA, USA) for $20 \mathrm{~min}$, both at $37^{\circ} \mathrm{C}$ in the dark. For DNA staining, cells were incubated with $1 / 200$ dilution of $1 \mu \mathrm{g} / \mathrm{mL}$ Hoechst 33342 (B2261, Sigma, St. Louis, MO, USA) for $5 \mathrm{~min}$ at $37^{\circ} \mathrm{C}$ in the dark.

The fluorescence was monitored with a Leica TCS-SPE Confocal Microscope, using $63 \times$ immersion oil (147 N.A.) objective lens. Fluorescence excitation/emission was 490/516 nm for MitoTracker Green, 577/590 for LysoTracker Red, and 350/455 nm for Hoechst 33342.

Mitochondrial Roundness was analyzed in ImageJ software with Mito-Morphology Macro designed by Ruben K. Dagda at the University of Pittsburgh (2010). This macro is currently maintained and supported by grants NIH/NINDS R01NS105783-01 grant and by NIH/NIGMS R25 1R25-OD023795-01.

\subsection{Seahorse Metabolic Analyzer}

Real-time oxygen consumption rates (OCRs) were determined for MCF7 and T47D cells using the Seahorse Extracellular Flux (XFe96) analyzer (Seahorse Bioscience, North Billerica, MA, USA). Cells were seeded at a density of $4.8 \times 10^{3}$ cells/well for MCF7 and 9.600 cells/well for T47D into XFe96 well cell culture plates and incubated overnight to allow attachment at $37{ }^{\circ} \mathrm{C}$ in $5 \% \mathrm{CO}_{2}$. After $24 \mathrm{~h}$, cells were incubated with vehicle or ELIT treatment. After $48 \mathrm{~h}$ of incubation, cells were maintained in $200 \mu \mathrm{L} /$ well of XF assay media at $37^{\circ} \mathrm{C}$, in a non- $\mathrm{CO}_{2}$ incubator for $1 \mathrm{~h}$. During the incubation time, mitochondrial complex inhibitors $(1 \mu \mathrm{M}$ oligomycin, $2 \mu \mathrm{M}$ FCCP, $0.5 \mu \mathrm{M}$ rotenone, and $0.5 \mu \mathrm{M}$ antimycin A) were preloaded for OCR measurements, in XF assay media into the injection ports in the XFe96 sensor cartridge. 


\subsection{Human Samples}

Human breast cancer biopsies were obtained from 33 women, ages between $45-90$ years. Samples of these patients were obtained from the Biological Specimen Bank of Son Llàtzer Hospital and as specified by and with the necessary permission granted from the Balearic Island Bioethics Committee. Tumor samples were collected immediately after tumor removal and were frozen in isopentane for analysis as described by Sastre-Serra et al. [38] Written informed consent was obtained from the patients before surgery. All the patients presented an invasive ductal carcinoma (ER-positive, PR-negative, and HER2-negative, as determined by immunohistochemistry) and were classified in normal weight (nw), overweight (ow), and obese (o) by BMI $\left(\mathrm{kg} / \mathrm{m}^{2}\right)$.

\subsection{Statistical Analysis}

The statistical analyses were performed with the Statistical Programme for the Social Sciences software for Windows (SPSS, version 27.0; SPSS Inc, Chicago, IL, USA). Data are presented as mean \pm standard error of the mean (SEM). The statistical differences in cell lines between vehicle- and ELIT-treated cells were analyzed using a Student's $t$-test with statistical significance was set at $p<0.05\left(^{*}\right)$. The statistical differences in human samples were analyzed using Pearson's correlation with statistical significance was set at $p<0.01$ $(* *)$ and $p<0.05(*)$.

\section{Results}

3.1. Obesity-Related Inflammation Treatment Increases Inflammation-Related Genes Expression in Breast Cancer Cell Lines

To confirm the obesity-related inflammation treatment effectivity, mRNA expression of main inflammatory genes was determined. As shown in Figure 1, inflammatory genes expression (IL6, IL6R, CXCL8, PTGS2, TNF, and STAT3) showed a statistically significant increase in both MCF7 and T47D cell lines after $24 \mathrm{~h}$ of ELIT (17 $\beta$-estradiol $(10 \mathrm{nM})$, leptin $(100 \mathrm{ng} / \mathrm{mL})$, interleukin-6 $(50 \mathrm{ng} / \mathrm{mL})$, and TNF $\alpha(10 \mathrm{ng} / \mathrm{mL}))$ treatment. In contrast, PPARG anti-inflammatory gene had decreased expression in the MCF7 cell line, and TGFB anti-inflammatory gene showed a statistically significant increase in the T47D cell line.

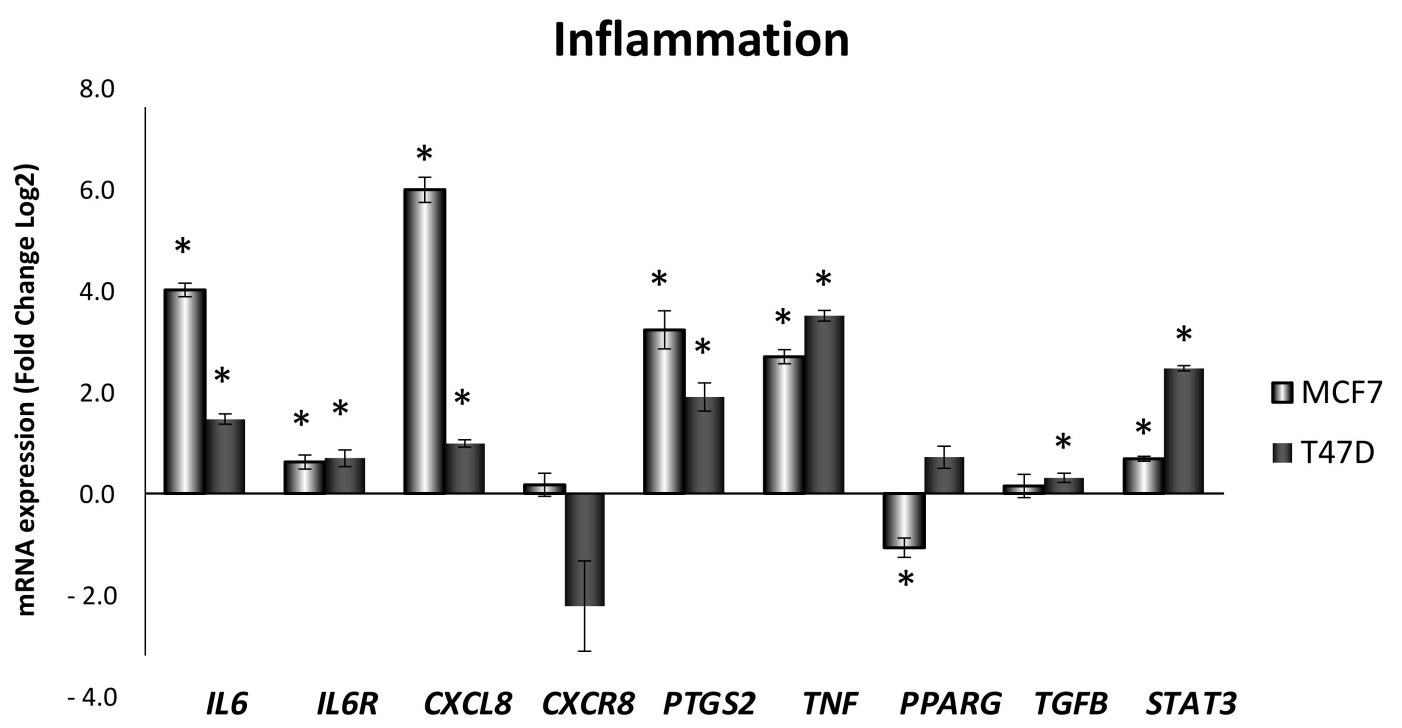

Figure 1. Obesity-related inflammation treatment increased the expression of genes related to inflammation in MCF7 and T47D breast cancer cell lines. IL6: interleukin-6; IL6R: interleukin-6 receptor; CXCL8: interleukin-8; CXCR8: interleukin-8 receptor; PTGS2: cyclooxygenase-2; TNF, tumor necrosis factor alpha; PPARG: peroxisome proliferator-activated receptor gamma; TGFB: transforming growth factor beta; STAT3: Signal transducer and activator of transcription 3. Breast cancer cells were incubated for $24 \mathrm{~h}$ with vehicle (DMSO) or ELIT. Data are represented as fold change $(\log 2)$ of mRNA expression with respect to vehicle-treated cells, set at 0 , of each cell line. Data represent means \pm SEM $(n=6)$. * Statistically significant difference between ELIT treated and vehicle-treated cells (Student's $t$-test, $p<0.05$ ). 


\subsection{Obesity-Related Inflammation Treatment Increases Oxidative Stress in Breast Cancer Cell Lines with High ER $\alpha / E R \beta$ Ratio}

As shown in Table 2, ELIT treatment, an increase ROS production in both MCF7 and T47D cell lines was seen. Superoxide anion levels increased more than 10 times in MCF7 cells $(1177 \%)$ and 5 times in T47D cells (526\%) after ELIT treatment, as shown in Table 2, and $\mathrm{H}_{2} \mathrm{O}_{2}$ production increased in both cell lines $(+100 \%$ in MCF7 and $+34 \%$ in T47D cells). However, cardiolipin content, as an indicator of mitochondrial inner membrane quantity, decreased in MCF7 treated cells. Moreover, as shown in Table 2, oxidative damage increased $(+45 \%)$ in MCF7 cell line after ELIT treatment, but not in the T47D cell line. A representative blot of 4-HNE detection is shown in Supplementary Materials Figure S2.

Table 2. Oxidative stress in MCF7 and T47D breast cancer cell lines.

\begin{tabular}{|c|c|c|c|c|}
\hline & \multicolumn{2}{|c|}{ MCF7 } & \multicolumn{2}{|c|}{ T47D } \\
\hline & Control & ELIT & Control & ELIT \\
\hline Superoxide anion levels (\%) & $100 \pm 13$ & $1177 \pm 116^{*}$ & $100 \pm 16$ & $526 \pm 35 *$ \\
\hline $\mathrm{H}_{2} \mathrm{O}_{2}$ production $(\%)$ & $100 \pm 1$ & $200 \pm 8^{*}$ & $100 \pm 2$ & $134 \pm 3^{*}$ \\
\hline Cardiolipin content (\%) & $100 \pm 2$ & $82.7 \pm 1.1^{*}$ & $100 \pm 1$ & $101 \pm 1$ \\
\hline Oxidative damage (\%) & $100 \pm 5$ & $145 \pm 8^{*}$ & $100 \pm 7$ & $92.3 \pm 11.7$ \\
\hline
\end{tabular}

Data represent the means $\pm \operatorname{SEM}(n=6)$. Values of control (DMSO-treated) cells were set at 100 in each cell line. * Significant difference between ELIT-treated and control cells (Student's test; $p<0.05$ ).

The mRNA expression of antioxidant enzymes was analyzed (Figure 2) in both MCF7 and T47D cell lines after $24 \mathrm{~h}$ ELIT treatment. As shown in Figure 2, SOD2 (mitochondrial superoxide dismutase) showed a high increase in both cell lines; in addition, a decrease in SOD1 (copper/zinc superoxide dismutase) was observed. However, ELIT-treated MCF7 cells showed a general decrease in catalase (CAT) and glutathione reductase (GSR). Nevertheless, in the T47D cell line, ELIT treatment increased GSR and nuclear factor erythroid 2-related factor 2 (NFE2L2) expression, as shown in Figure 2.

Main antioxidant protein expression levels were determined (Table 3 and Supplementary Materials) after $48 \mathrm{~h}$ ELIT treatment and resulted in a high increase in SOD2 in both MCF7 and T47D cell lines (more than 10 times in MCF7 and 30 times in T47D). Moreover, SOD1 showed a statistically significant increase in the T47D cell line after treatment. As shown in Table 3, CAT and GSR protein levels decrease only in the MCF7 cell line after ELIT treatment ( $-30 \%$ and $-51 \%$, respectively). Representative detection bands are shown in Supplementary Materials Figures S3-S6.

Table 3. Antioxidant enzymes protein levels in MCF7 and T47D breast cancer cell lines.

\begin{tabular}{ccccc}
\hline & \multicolumn{2}{c}{ MCF7 } & \multicolumn{2}{c}{ T47D } \\
\cline { 2 - 5 } & Control & ELIT & Control & ELIT \\
\hline SOD1 (\%) & $100 \pm 12$ & $89 \pm 14$ & $100 \pm 25$ & $156 \pm 28^{*}$ \\
SOD2 (\%) & $100 \pm 11$ & $1631 \pm 552^{*}$ & $100 \pm 15$ & $3691 \pm 350^{*}$ \\
CAT (\%) & $100 \pm 6$ & $70 \pm 8^{*}$ & $100 \pm 14$ & $88 \pm 10$ \\
GSR (\%) & $100 \pm 14$ & $49 \pm 6^{*}$ & $100 \pm 9$ & $117 \pm 8$ \\
\hline
\end{tabular}

Data represent the means \pm SEM $(n=6)$. Values of control (DMSO-treated) cells were set at 100 in each cell line.

* Significant difference between ELIT-treated and control cells (Student's test; $p<0.05$ ). 


\section{Oxidative Stress}

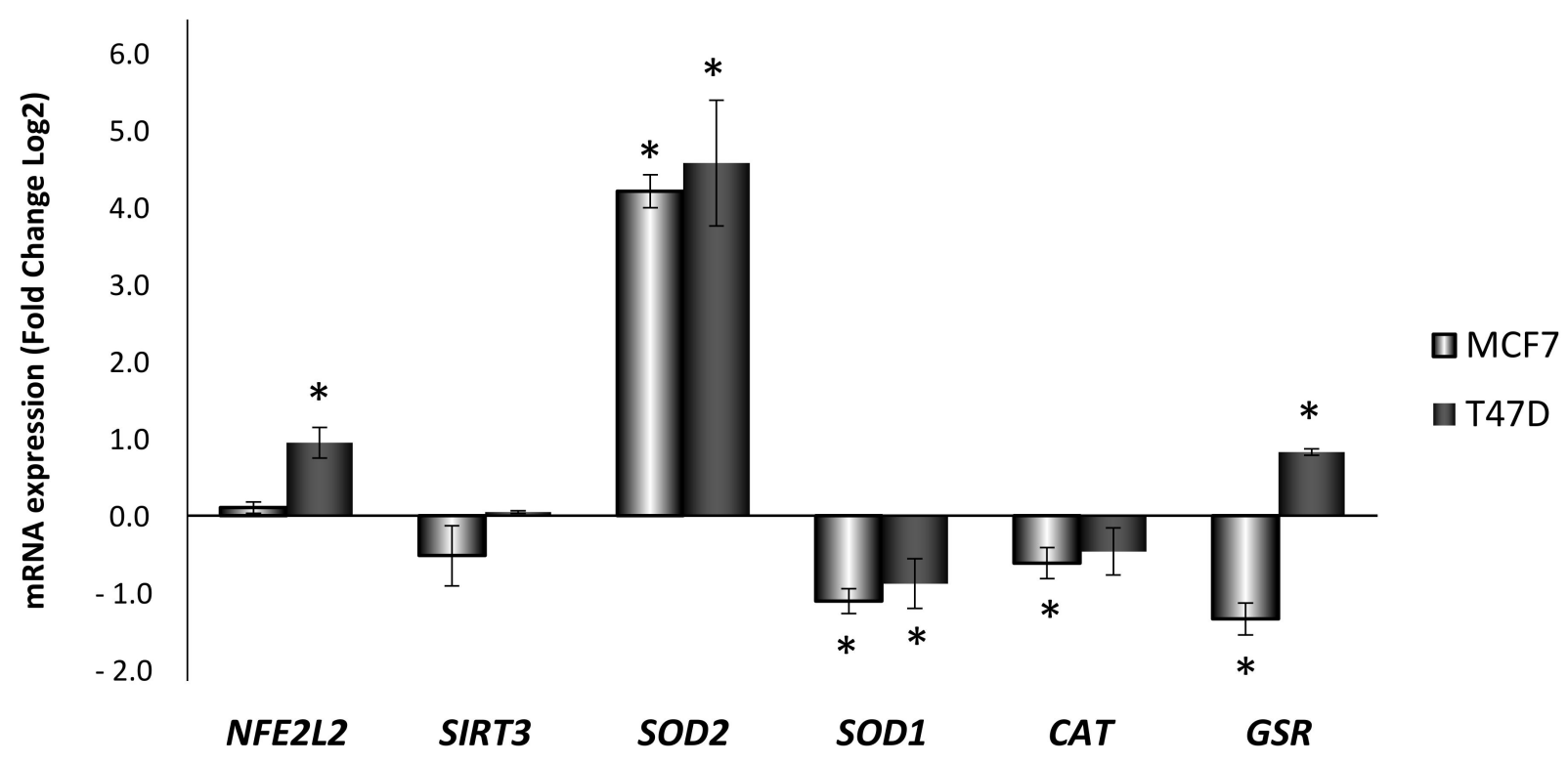

Figure 2. Obesity-related inflammation treatment modified expression of genes related to oxidative stress in MCF7 and T47D breast cancer cell lines. NFE2L2: nuclear factor erythroid 2-related factor 2; SIRT3: sirtuin 3; SOD2: manganese superoxide dismutase; SOD1: copper/zinc superoxide dismutase; CAT: catalase; GSR: glutathione reductase. Breast cancer cells were incubated for $24 \mathrm{~h}$ with vehicle (DMSO) or ELIT. Data are represented as fold change (log2) of mRNA expression with respect to vehicle-treated cells, set at 0 , of each cell line. Data represent means \pm SEM $(n=6)$. * Statistically significant difference between treated and vehicle-treated cells (Student's $t$-test, $p<0.05$ ).

\subsection{Mitochondrial Biogenesis and Functionality Are Reduced in Breast Cancer Cell Lines after ELIT Treatment with a High ER $\alpha / E R \beta$ Ratio}

Mitochondrial biogenesis genes were also checked, as shown in Figure 3. ELIT treatment decreased the expression of almost all mitochondrial biogenesis genes analyzed in MCF7 cell line. Nevertheless, in the T47D cell line, not only did the mRNA expression not decrease but also, especially high levels of estrogen-related receptor alpha (ESRRA) and Twinkle (TWNK) were found in ELIT-treated cells versus non-treated cells. Moreover, uncoupling proteins 2 and 5 (UCP2 and SLC25A14, respectively) mRNA expression was analyzed, and a decrease in UCP2 expression in both cell lines was accompanied by a decrease in uncoupling protein 5 expression in the MCF7 cell line.

Mitochondrial biogenesis master regulator PPARGC1A protein levels increased after ELIT treatment in the MCF7 cell line. However, to check the effect of ELIT treatment on the mitochondrial respiratory chain (OXPHOS), protein levels of these OXPHOS complexes were analyzed. As seen in Table 4 and Supplementary Materials, ELIT treatment did not change protein levels in T47D, whereas, in MCF7 cell line OXPHOS complexes, protein levels decreased, except complex III (Q-cytochrome c oxidoreductase) after $48 \mathrm{~h}$ treatment. Representative detection bands are shown in Supplementary Materials in Figures S7 and S8. 


\section{Mitochondrial Biogenesis}

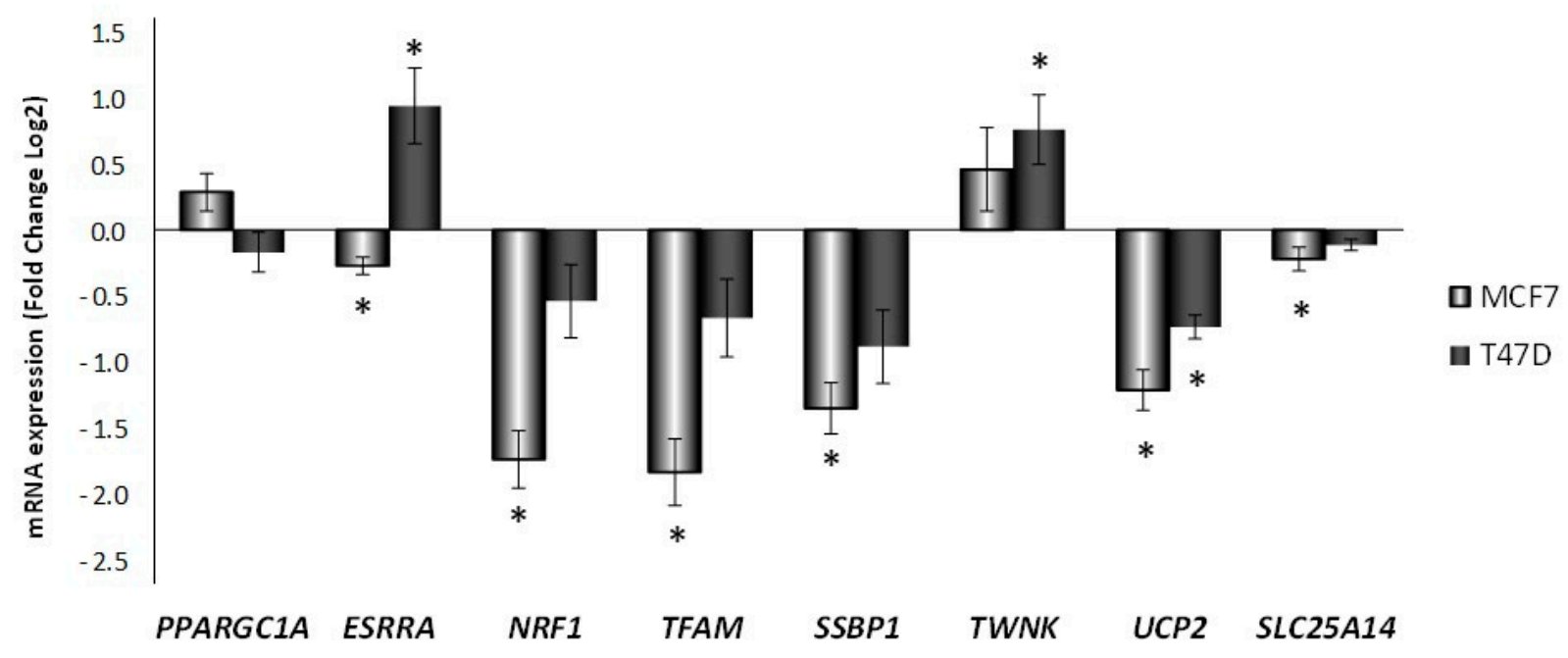

Figure 3. Obesity-related inflammation treatment modified expression of genes related to mitochondrial biogenesis in MCF7 and T47D breast cancer cell lines. PPARGC1A: peroxisome proliferator-activated receptor-gamma coactivator-1alpha; ESRRA: estrogen-related receptor alpha; NRF1: nuclear respiratory factor 1; TFAM: mitochondrial transcription factor A; SSBP1: mitochondrial single-strand DNA binding protein; TWNK: Twinkle mtDNA helicase; UCP2: uncoupling protein 2; SLC25A14: uncoupling protein 5 . Breast cancer cells were incubated for $24 \mathrm{~h}$ with vehicle (DMSO) or ELIT. Data are represented as fold change $(\log 2)$ of mRNA expression with respect to vehicle-treated cells, set at 0 , of each cell line. Data represent means \pm SEM $(n=6) .{ }^{*}$ Statistically significant difference between treated and vehicle-treated cells (Student's $t$-test, $\left.p<0.05\right)$.

Table 4. Mitochondrial-related protein levels in MCF7 and T47D breast cancer cell lines.

\begin{tabular}{ccccc}
\hline & \multicolumn{3}{c}{ MCF7 } & T47D \\
\cline { 2 - 5 } & Control & ELIT & Control & ELIT \\
\hline PPARGC1A (\%) & $100 \pm 11$ & $142 \pm 2^{*}$ & $100 \pm 13$ & $91 \pm 16$ \\
Complex I (NDUFB8) (\%) & $100 \pm 7$ & $36 \pm 2^{*}$ & $100 \pm 16$ & $80 \pm 21$ \\
Complex II (SDHB) (\%) & $100 \pm 17$ & $39 \pm 4^{*}$ & $100 \pm 18$ & $84 \pm 10$ \\
Complex III (UQCRC2) (\%) & $100 \pm 40$ & $136 \pm 24$ & $100 \pm 5$ & $101 \pm 8$ \\
Complex IV (COX II) (\%) & $100 \pm 10$ & $26 \pm 4^{*}$ & $100 \pm 18$ & $65 \pm 13$ \\
(COX IV) (\%) & $100 \pm 5$ & $54 \pm 6^{*}$ & $100 \pm 3$ & $86 \pm 13$ \\
Complex V (ATP5A) (\%) & $100 \pm 9$ & $56 \pm 10^{*}$ & $100 \pm 14$ & $117 \pm 4$ \\
\hline
\end{tabular}

Data represent the means $\pm \operatorname{SEM}(n=6)$. Values of control (DMSO-treated) cells were set at 100 in each cell line. * Significant difference between ELIT-treated and control cells (Student's test; $p<0.05$ ).

To further investigate mitochondrial function, the oxygen consumption rate (OCR) was determined. As shown in Figure 4a,c, basal OCR, Maximal respiratory capacity, ATPlinked respiration, and proton leak were statistically significantly lower in the MCF7 cell line after ELIT $48 \mathrm{~h}$ treatment. These changes were not observed in the T47D cell line (Figure $4 \mathrm{~b}, \mathrm{~d}$ ). Moreover, reserve capacity, calculated as basal minus maximal respiratory capacity rates, showing an increase in both cell lines, though this increase was higher in the T47D than in the MCF7 cell line. 

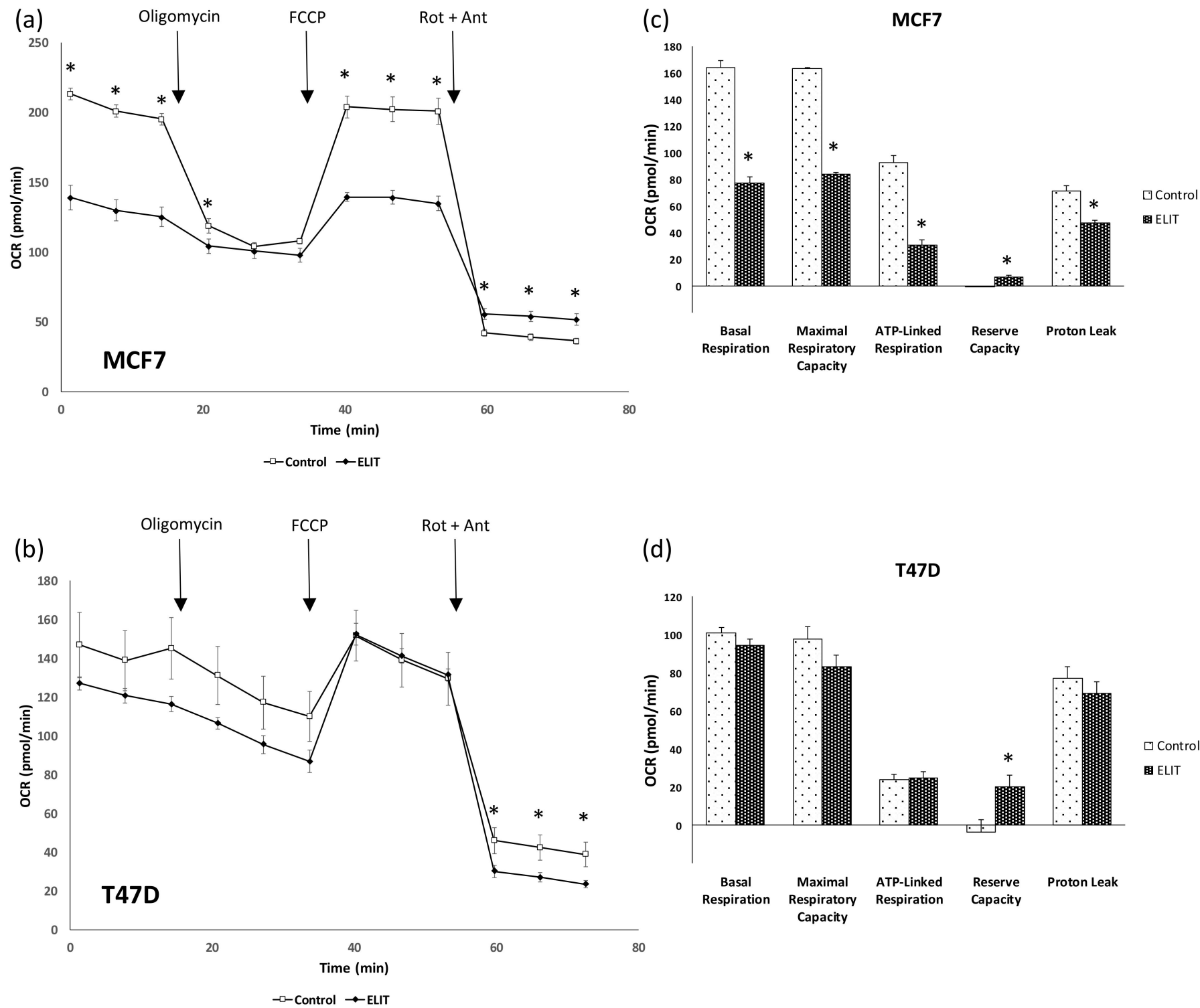

(d)

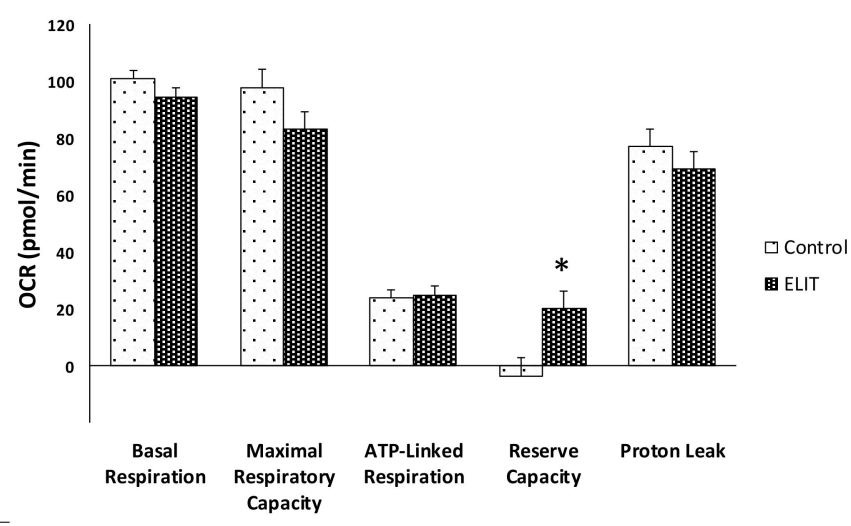

Figure 4. ELIT treatment reduced oxygen consumption ratio (OCR) in the MCF7 cell line. (a,b): OCR basal conditions and after oligomycin, FCCP, and antimycin A + rotenone addition. (c,d): calculated parameters from oxygen consumption analysis. Basal respiration: initial rate-antimycin A + rotenone rate; ATP-Linked Respiration: maximal respiratory capacity: FCCP rate-antimycin A+ rotenone rate; initial rate-oligomycin rate; Reserve capacity: FCCP rate-initial rate; proton leak: oligomycin rate-antimycin A+ rotenone rate. Values are expressed as means \pm SEM $(n=5) .{ }^{*}$ Statistically significant difference between treated and vehicle-treated cells (Student's $t$-test, $p<0.05$ ).

\subsection{Obesity-Related Inflammation Treatment Affects Mitochondrial Dynamics and Mitochondrial Network in Breast Cancer Cell Lines \\ As shown in Figure 5, mitochondrial dynamics genes expression was decreased in MCF7 cells after $24 \mathrm{~h}$ ELIT treatment, but in T47D treated cells, this situation was not observed. In fact, almost all the genes showed an increase after treatment in this cell line. The expression of mitochondrial fusion-related genes MFN1, MFN2, OMA1, OPA1 showed decreased levels in the MCF7 cell line, whereas, in the T47D cell line, ELIT treatment increased expression of MFN1, MFN2, and OMA1. Fission-related mitochondrial genes presented a different pattern expression between cell lines, with a statistically significant increase in FIS1 mRNA expression in the T47D cell line after ELIT treatment.}




\section{Mitochondrial Dynamics}

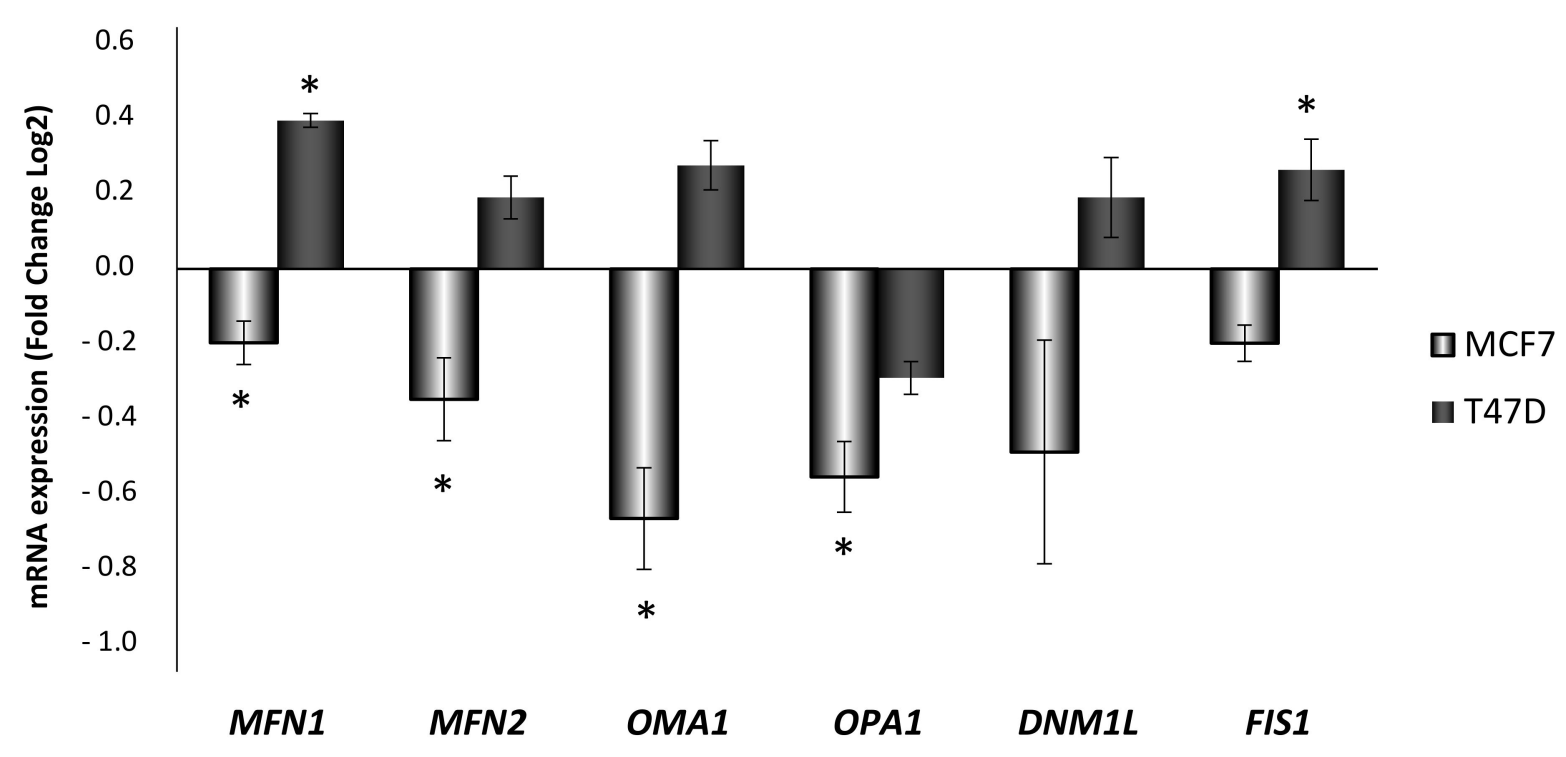

Figure 5. Obesity-related inflammation treatment modified expression of genes related to mitochondrial dynamics in MCF7 and T47D breast cancer cell lines. MFN1: mitofusin-1; MFN2: mitofusin-2; OPA1: mitochondrial dynamin-like GTPase; OMA1: zinc metallopeptidase; DNM1L: dynamin 1 like; FIS1: mitochondrial fission 1 protein. Breast cancer cells were incubated for $24 \mathrm{~h}$ with vehicle (DMSO) or ELIT. Data are represented as fold change (log2) of mRNA expression with respect to vehicle-treated cells, set at 0 , of each cell line. Data represent means $\pm \operatorname{SEM}(n=6) .{ }^{*}$ Statistically significant difference between treated and vehicle-treated cells (Student's $t$-test, ${ }^{*} p<0.05$ ).

On the one hand, mitochondrial networking was modified after $24 \mathrm{~h}$-ELIT treatment in both MCF7 and T47D cell lines. However, as shown in Figure 6a, the MTG signal was higher in the MCF7 cell line after treatment, but LTR intensity was also high. These changes were not observed in T47D cell lines after ELIT treatment. On the other hand, lysosomes distribution in MCF7 cell lines, whereas more equally distributed dispersed through the cytoplasm after 24 h-ELIT treatment, whereas in T47D cell line this distribution showed seemed to be more perinuclear. Index of elongation, calculated as the average circularity of mitochondria of confocal microscopy images, as shown in Figure 6b. As seen, the MCF7 cell line after $24 \mathrm{~h}$ ELIT treatment showed more circular mitochondria than in control cells. These morphological modifications were not seen in the T47D cell line with treatment.

\subsection{Obesity-Related Inflammation Treatment Increase Invasiveness in Breast Cancer Cell Lines} with a High ER $\alpha / E R \beta$ Ratio

As shown in Figure 7a, Cadherin E (CDH1) expression was decreased in MCF7 cells after $24 \mathrm{~h}$ ELIT treatment, but Matrix Metalloproteinase 9 (MMP9) expression increased three times with respect to vehicle-treated cells. In contrast, CDH1 expression increased in the T47D cell line after treatment. In addition to these results, a wound-healing assay was performed. As shown in Figure $7 \mathrm{~b}$ and in Supplementary Materials Figure S9, after $24 \mathrm{~h}$, ELIT-treated MCF7 cells were able to better close the wound, leaving $80 \%$ of the initial scratch open, while the control cells were not able to close the wound. In the T47D cell line, there were no differences between control and ELIT-treated cells. 

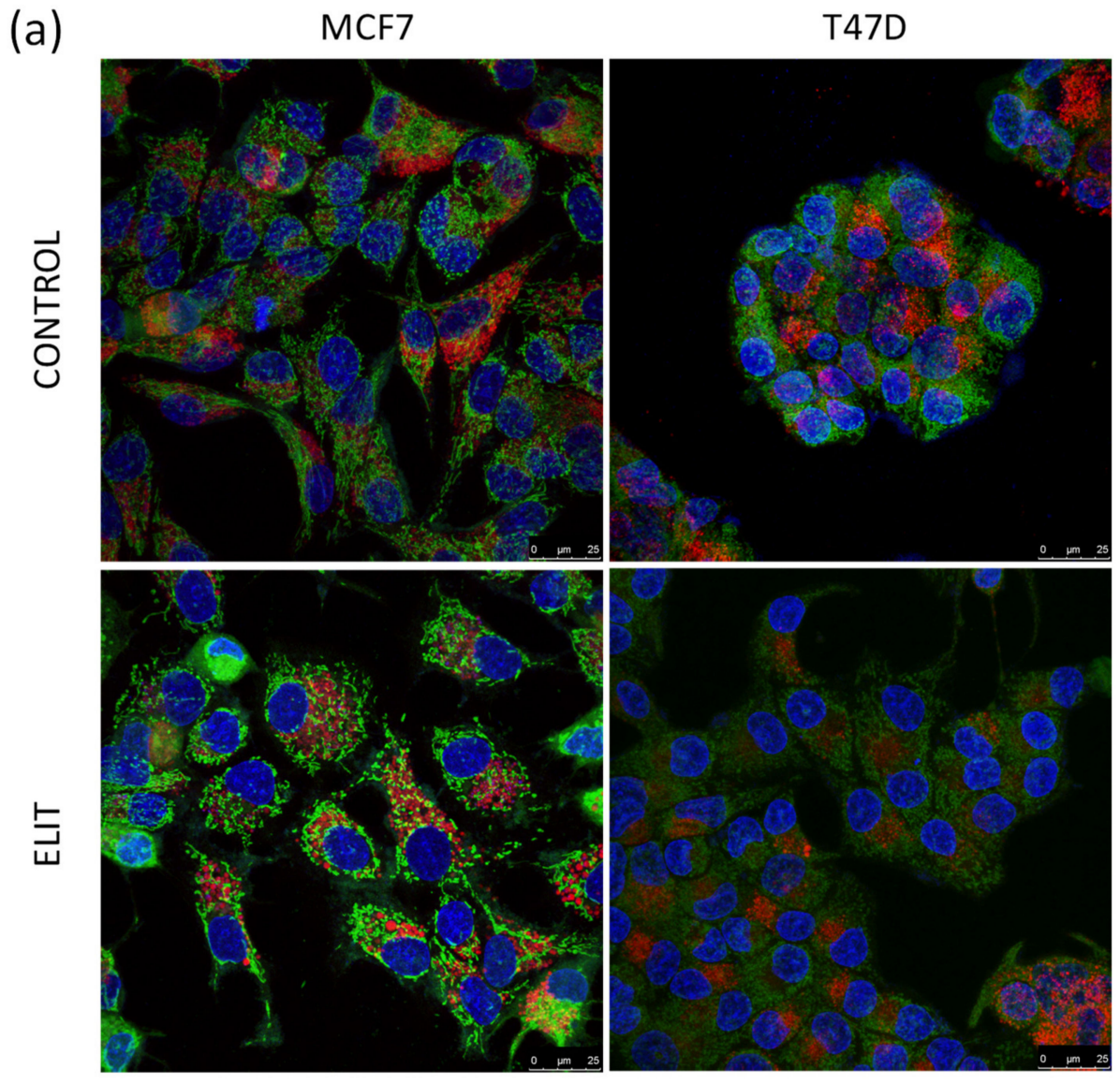

(b)
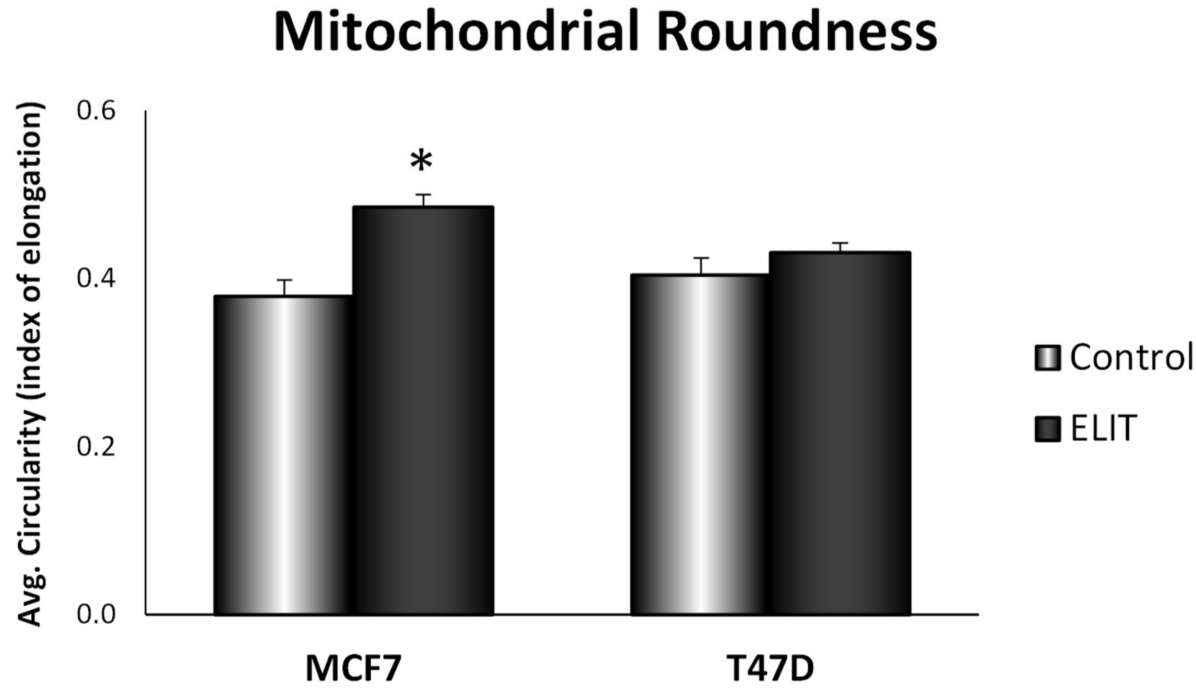

Figure 6. ELIT treatment induces mitochondrial networking changes in the MCF7 cell line. (a) Breast cancer cell lines MCF7 and T47D were treated with ELIT for $24 \mathrm{~h}$ followed by co-incubation with MTG, LTR, and Hoechst 33342. The fluorescence was monitored with a Leica Confocal Microscope using $63 \times$ oil 147 N.A. objective lens. Scale bar $25 \mu \mathrm{m}$. (b) Mitochondrial Roundness was analyzed with ImageJ Software. Breast cancer cells were incubated for $24 \mathrm{~h}$ with vehicle (DMSO) or ELIT. Data are represented as an index of elongation, set at one when a perfect circle. Data represent means \pm SEM $(n=6) .{ }^{*}$ Statistically significant difference between treated and vehicle-treated cells (Student's $t$-test, $\left.{ }^{*} p<0.05\right)$. 

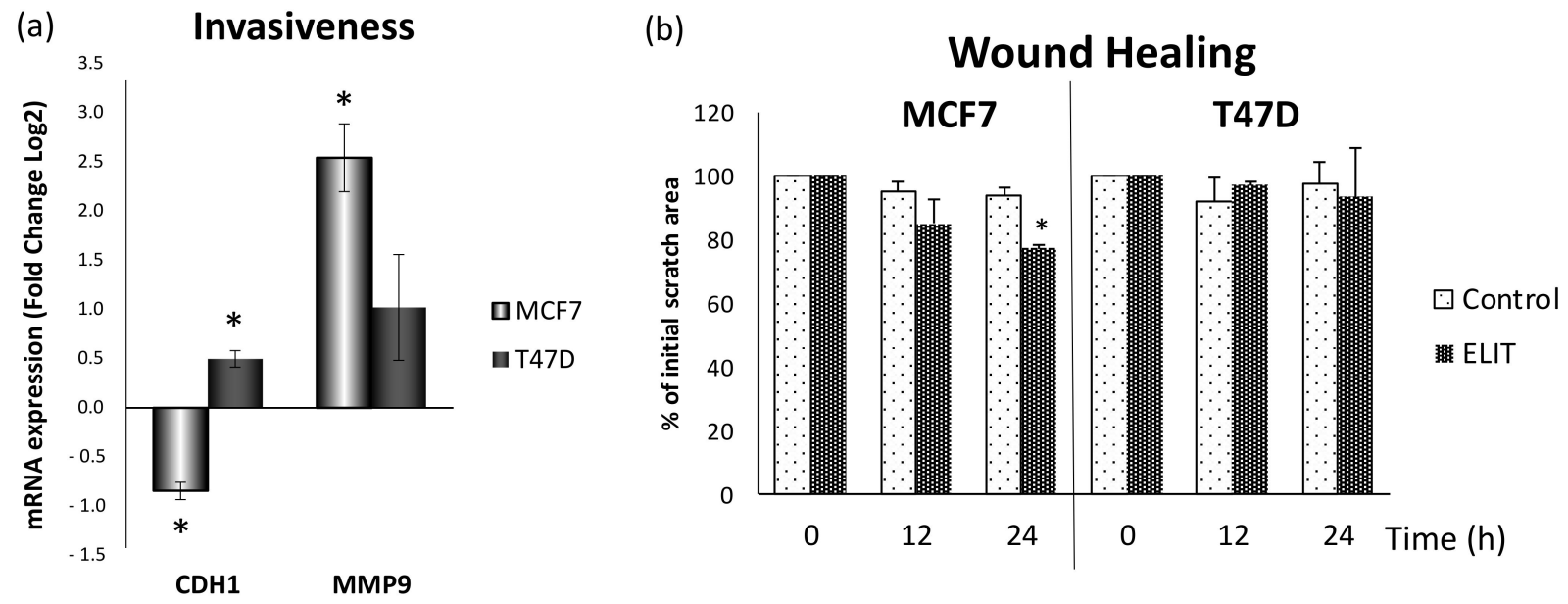

Figure 7. Invasiveness and cell motility were increased after ELIT treatment in the MCF7 cell line. (a) CDH1: cadherin-E; MMP9: Matrix Metalloproteinase 9. Breast cancer cells were incubated for $24 \mathrm{~h}$ with vehicle (DMSO) or ELIT. Data are represented as fold change $(\log 2)$ of mRNA expression with respect to vehicle-treated cells, set at 0 , of each cell line. Data represent means $\pm \operatorname{SEM}(n=6)$. (b) Area of the wound that remained open after $24 \mathrm{~h}$ with ELIT treatment. Data are represented as a percentage of the initial scratch area with respect to vehicle-treated cells of each well, set at 100, of each cell line. Data represent means $\pm \operatorname{SEM}(n=3) .{ }^{*}$ Statistically significant difference between treated and vehicle-treated cells (Student's $t$-test, $p<0.05$ ).

\subsection{Estrogen Receptor Ratio Is Modified by ELIT Treatment in Breast Cancer Cell Lines}

To observe the effects of obesity-related inflammation treatment over estrogen receptors alpha $(\mathrm{ER} \alpha)$, beta $(\mathrm{ER} \beta)$, and GPER in MCF7 and T47D breast cancer cell lines, mRNA expression was analyzed. As shown in Figure 8, estrogen receptor alpha (ESR1) mRNA expression was decreased in both cell lines after $24 \mathrm{~h}$-ELIT treatment. However, estrogen receptor beta (ESR2) and GPER (GPER1) mRNA expression only shown a decrease in the MCF7 cell line, maintaining its expression in the T47D cell line.

\section{Estrogen Receptors}

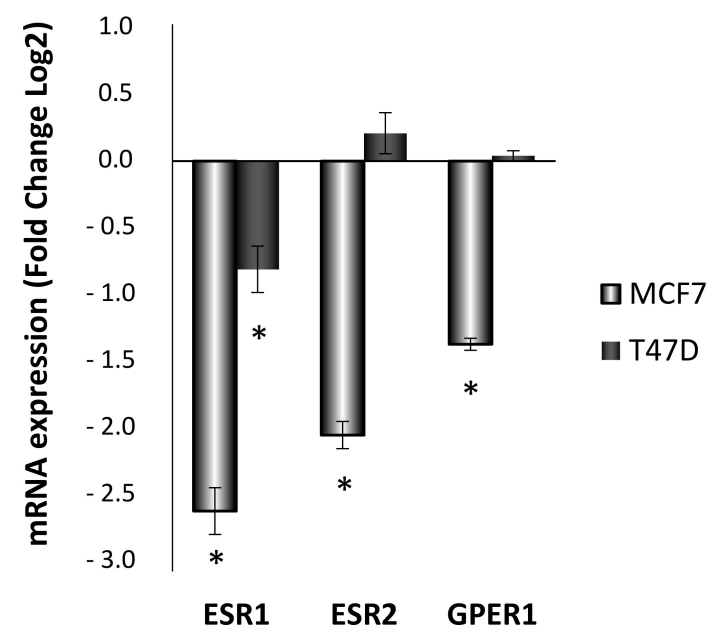

Figure 8. Obesity-related inflammation treatment modified expression of estrogen receptor alpha, beta, and GPER in MCF7 and T47D breast cancer cell lines. ESR1: estrogen receptor alpha; ESR2: estrogen receptor beta; GPER1: G-coupled protein estrogen receptor. Breast cancer cells were incubated for $24 \mathrm{~h}$ with vehicle (DMSO) or ELIT. Data are represented as fold change (log2) of mRNA expression with respect to vehicle-treated cells, set at 0 , of each cell line. Data represent means $\pm \operatorname{SEM}(n=6)$. * Statistically significant difference between treated and vehicle-treated cells (Student's $t$-test, ${ }^{*} p<0.05$ ). 
3.7. IL6R in Breast Tumors Correlates with Inflammation, Mitochondrial Biogenesis, and Oxidative Stress Markers in Different BMI Situations

Table 5 shows the correlation with Pearson correlation values between the IL6R mRNA expression and studied genes in different BMI situations: normal weight (nw), overweight (ow), and obese (o). CXCR8, CXCL8, TNF, SLC25A14, NRF1, NFE2L2, PPARGC1A, and FIS1 were significantly and positively correlated with IL6R expression in the nw group. CXCR8, TNF, SLC25A14, NRF1, NFE2L2, and PPARGC1A were significantly and positively correlated with IL6R expression in the ow group. CXCR8, CXCL8, TNF, PTGS2, ESR2, GPX1, SOD1, SLC25A14, NRF1, NFE2L2, PPARGC1A, SIRT1, FIS1, and OMA1 were significantly and positively correlated with IL6R expression in the ow group.

Table 5. Correlation values of IL6R gene expression in breast tumors according to obesity status.

\begin{tabular}{|c|c|c|c|c|c|c|c|c|c|c|c|c|c|c|}
\hline & & nw & ow & o & & & nw & ow & o & & & nw & ow & o \\
\hline \multirow{3}{*}{ IL6R } & Pearson & & & & \multirow{3}{*}{ CAT } & Pearson & & & & \multirow{3}{*}{ SSBP1 } & Pearson & & & \\
\hline & $\begin{array}{l}\text { Corre- } \\
\text { lation }\end{array}$ & 1 & 1 & 1 & & $\begin{array}{l}\text { Corre- } \\
\text { lation }\end{array}$ & -0.205 & 0.421 & 0.164 & & $\begin{array}{l}\text { Corre- } \\
\text { lation }\end{array}$ & 0.306 & -0.218 & 0.229 \\
\hline & Sig. & & & & & Sig. & 0.285 & 0.173 & 0.272 & & Sig. & 0.195 & 0.319 & 0.197 \\
\hline \multirow[t]{2}{*}{ ESR1 } & $\begin{array}{l}\text { Pearson } \\
\text { Corre- } \\
\text { lation }\end{array}$ & -0.006 & 0.105 & -0.337 & \multirow[t]{2}{*}{ GPX1 } & $\begin{array}{l}\text { Pearson } \\
\text { Corre- } \\
\text { lation }\end{array}$ & 0.358 & 0.406 & $0.704^{* *}$ & \multirow[t]{2}{*}{ NRF1 } & $\begin{array}{l}\text { Pearson } \\
\text { Corre- } \\
\text { lation }\end{array}$ & $\underset{* *}{0.870}$ & $\underset{* *}{0.878}$ & $\underset{* *}{0.936}$ \\
\hline & Sig. & 0.494 & 0.412 & 0.101 & & Sig. & 0.155 & 0.183 & 0.001 & & Sig. & 0.001 & 0.005 & 0 \\
\hline \multirow[t]{2}{*}{ ESR2 } & $\begin{array}{c}\text { Pearson } \\
\text { Corre- } \\
\text { lation }\end{array}$ & 0.396 & 0.703 & 0.605 * & \multirow[t]{2}{*}{ GSR } & $\begin{array}{l}\text { Pearson } \\
\text { Corre- } \\
\text { lation }\end{array}$ & 0.454 & 0.286 & -0.009 & \multirow[t]{2}{*}{$\begin{array}{c}\text { PPARGC1 } \\
\text { A }\end{array}$} & $\begin{array}{c}\text { Pearson } \\
\text { Corre- } \\
\text { lation }\end{array}$ & $\begin{array}{c}0.656 \\
*\end{array}$ & $\begin{array}{c}0.807 \\
*\end{array}$ & $\underset{* *}{0.830}$ \\
\hline & Sig. & 0.19 & 0.059 & 0.024 & & Sig. & 0.094 & 0.267 & 0.486 & & Sig. & 0.02 & 0.014 & 0 \\
\hline \multirow[t]{2}{*}{ CXCR8 } & $\begin{array}{l}\text { Pearson } \\
\text { Corre- } \\
\text { lation }\end{array}$ & 0.791 ** & $0.840 * *$ & $0.957 * *$ & \multirow[t]{2}{*}{ SOD1 } & $\begin{array}{l}\text { Pearson } \\
\text { Corre- } \\
\text { lation }\end{array}$ & 0.438 & 0.062 & $0.434^{*}$ & \multirow[t]{2}{*}{ SIRT1 } & $\begin{array}{l}\text { Pearson } \\
\text { Corre- } \\
\text { lation }\end{array}$ & 0.228 & 0.261 & $\underset{* *}{0.604}$ \\
\hline & Sig. & 0.003 & 0.009 & 0 & & Sig. & 0.103 & 0.448 & 0.046 & & Sig. & 0.263 & 0.286 & 0.007 \\
\hline \multirow[t]{2}{*}{ IL6R } & $\begin{array}{l}\text { Pearson } \\
\text { Corre- } \\
\text { lation }\end{array}$ & 0.421 & 0.113 & 0.304 & \multirow[t]{2}{*}{ SOD2 } & $\begin{array}{l}\text { Pearson } \\
\text { Corre- } \\
\text { lation }\end{array}$ & 0.289 & -0.459 & -0.106 & \multirow[t]{2}{*}{ TFAM } & $\begin{array}{l}\text { Pearson } \\
\text { Corre- } \\
\text { lation }\end{array}$ & 0.279 & -0.037 & 0.387 \\
\hline & Sig. & 0.113 & 0.405 & 0.126 & & Sig. & 0.209 & 0.15 & 0.348 & & Sig. & 0.234 & 0.468 & 0.069 \\
\hline \multirow[t]{2}{*}{ CXCL8 } & $\begin{array}{l}\text { Pearson } \\
\text { Corre- } \\
\text { lation }\end{array}$ & $0.732^{* *}$ & 0.662 & $0.911 * *$ & \multirow[t]{2}{*}{ SIRT3 } & $\begin{array}{l}\text { Pearson } \\
\text { Corre- } \\
\text { lation }\end{array}$ & 0.428 & -0.11 & 0.3 & \multirow[t]{2}{*}{ FIS1 } & $\begin{array}{l}\text { Pearson } \\
\text { Corre- } \\
\text { lation }\end{array}$ & $\begin{array}{c}0.609 \\
*\end{array}$ & 0.326 & $\underset{* *}{0.883}$ \\
\hline & Sig. & 0.008 & 0.053 & 0 & & Sig. & 0.125 & 0.407 & 0.129 & & Sig. & 0.041 & 0.237 & 0 \\
\hline \multirow[t]{2}{*}{ TGFB } & $\begin{array}{c}\text { Pearson } \\
\text { Corre- } \\
\text { lation }\end{array}$ & 0.296 & -0.552 & 0.272 & \multirow[t]{2}{*}{ NFE2L2 } & $\begin{array}{l}\text { Pearson } \\
\text { Corre- } \\
\text { lation }\end{array}$ & $0.680 *$ & 0.753 * & $0.812^{* *}$ & \multirow[t]{2}{*}{ OMA1 } & $\begin{array}{c}\text { Pearson } \\
\text { Corre- } \\
\text { lation }\end{array}$ & 0.379 & 0.472 & $\underset{*}{0.541}$ \\
\hline & Sig. & 0.203 & 0.1 & 0.154 & & Sig. & 0.015 & 0.025 & 0 & & Sig. & 0.157 & 0.172 & 0.015 \\
\hline \multirow[t]{2}{*}{ TNF } & $\begin{array}{l}\text { Pearson } \\
\text { Corre- } \\
\text { lation }\end{array}$ & $0.604 *$ & 0.684 * & $0.806^{* *}$ & \multirow[t]{2}{*}{ UCP2 } & $\begin{array}{l}\text { Pearson } \\
\text { Corre- } \\
\text { lation }\end{array}$ & 0.256 & -0.266 & 0.332 & \multirow[t]{2}{*}{ OPA1 } & $\begin{array}{l}\text { Pearson } \\
\text { Corre- } \\
\text { lation }\end{array}$ & -0.39 & -0.45 & -0.032 \\
\hline & Sig. & 0.032 & 0.045 & 0 & & Sig. & 0.238 & 0.282 & 0.104 & & Sig. & 0.17 & 0.224 & 0.456 \\
\hline \multirow[t]{2}{*}{ PTGS2 } & $\begin{array}{l}\text { Pearson } \\
\text { Corre- } \\
\text { lation }\end{array}$ & 0.07 & -0.134 & $0.639 * *$ & \multirow[t]{2}{*}{$\begin{array}{c}\text { SLC25A } \\
14\end{array}$} & $\begin{array}{l}\text { Pearson } \\
\text { Corre- } \\
\text { lation }\end{array}$ & $0.874^{* *}$ & $0.901 * *$ & $0.940^{* *}$ & \multirow{2}{*}{\multicolumn{3}{|c|}{$\begin{array}{l}\text { * The correlation is significant at } \\
\qquad p<0.05 \\
\text { ** The correlation is significant } \\
\text { at } p<0.01\end{array}$}} & & \\
\hline & Sig. & 0.435 & 0.415 & 0.007 & & Sig. & 0 & 0.003 & 0 & & & & & \\
\hline
\end{tabular}

Data represent Pearson correlations and significance (unilateral) in normal weight $(n=9)$. overweight $(n=8)$ and obesity $(n=16)$ groups. $*(p<0.05){ }^{* *}(p<0.01)$ significant difference.

Moreover, ESR1 and ESR2 gene expression correlations are shown in Table 6a,b, respectively. On the one hand, IL6, CXCL8, SOD1, and SSBP1 were significantly and negatively correlated with ESR1 expression; instead, SIRT3 was significantly and positively correlated. On the other hand, IL6R, CXCR8, GPX1, SLC25A14, NRF1, PPARGC1A, SIRT1, and $O M A 1$ were significantly and positively correlated with ESR2 expression. 
Table 6. Correlation values of estrogen receptors subtype alpha and beta gene expression in breast tumors. (a) ESR1 correlation. (b) ESR2 correlation.

\begin{tabular}{|c|c|c|c|c|c|c|c|c|}
\hline \multicolumn{9}{|c|}{ (a) } \\
\hline \multirow[t]{2}{*}{ ESR1 } & $\begin{array}{c}\text { Pearson } \\
\text { Correlation }\end{array}$ & 1.000 & \multirow[t]{2}{*}{ CAT } & $\begin{array}{l}\text { Pearson } \\
\text { Correlation }\end{array}$ & 0.089 & \multirow[t]{2}{*}{ SSBP1 } & $\begin{array}{l}\text { Pearson } \\
\text { Correlation }\end{array}$ & -0.461 ** \\
\hline & Sig. & & & Sig. & 0.624 & & Sig. & 0.007 \\
\hline \multirow[t]{2}{*}{ IL6R } & $\begin{array}{l}\text { Pearson } \\
\text { Correlation }\end{array}$ & -0.219 & \multirow[t]{2}{*}{ GPX1 } & $\begin{array}{l}\text { Pearson } \\
\text { Correlation }\end{array}$ & 0.218 & \multirow[t]{2}{*}{ NRF1 } & $\begin{array}{l}\text { Pearson } \\
\text { Correlation }\end{array}$ & -0.154 \\
\hline & Sig. & 0.221 & & Sig. & 0.223 & & Sig. & 0.393 \\
\hline \multirow[t]{2}{*}{ ESR2 } & $\begin{array}{l}\text { Pearson } \\
\text { Correlation }\end{array}$ & 0.010 & \multirow[t]{2}{*}{ GSR } & $\begin{array}{l}\text { Pearson } \\
\text { Correlation }\end{array}$ & 0.139 & \multirow[t]{2}{*}{ PPARGC1A } & $\begin{array}{l}\text { Pearson } \\
\text { Correlation }\end{array}$ & -0.314 \\
\hline & Sig. & 0.962 & & Sig. & 0.440 & & Sig. & 0.075 \\
\hline \multirow[t]{2}{*}{ CXCR8 } & $\begin{array}{l}\text { Pearson } \\
\text { Correlation }\end{array}$ & -0.230 & \multirow[t]{2}{*}{ SOD1 } & $\begin{array}{l}\text { Pearson } \\
\text { Correlation }\end{array}$ & -0.391 * & \multirow[t]{2}{*}{ SIRT1 } & $\begin{array}{l}\text { Pearson } \\
\text { Correlation }\end{array}$ & -0.012 \\
\hline & Sig. & 0.205 & & Sig. & 0.024 & & Sig. & 0.945 \\
\hline \multirow[t]{2}{*}{ IL6 } & $\begin{array}{c}\text { Pearson } \\
\text { Correlation }\end{array}$ & $-0.364 *$ & \multirow[t]{2}{*}{ SOD2 } & $\begin{array}{c}\text { Pearson } \\
\text { Correlation }\end{array}$ & 0.177 & \multirow[t]{2}{*}{ TFAM } & $\begin{array}{c}\text { Pearson } \\
\text { Correlation }\end{array}$ & -0.003 \\
\hline & Sig. & 0.037 & & Sig. & 0.323 & & Sig. & 0.989 \\
\hline \multirow[t]{2}{*}{ CXCL8 } & $\begin{array}{l}\text { Pearson } \\
\text { Correlation }\end{array}$ & -0.422 * & \multirow[t]{2}{*}{ SIRT3 } & $\begin{array}{l}\text { Pearson } \\
\text { Correlation }\end{array}$ & $0.571 * *$ & \multirow[t]{2}{*}{ FIS1 } & $\begin{array}{l}\text { Pearson } \\
\text { Correlation }\end{array}$ & -0.192 \\
\hline & Sig. & 0.014 & & Sig. & 0.001 & & Sig. & 0.292 \\
\hline \multirow[t]{2}{*}{ TGFB } & $\begin{array}{c}\text { Pearson } \\
\text { Correlation }\end{array}$ & 0.221 & \multirow[t]{2}{*}{ NFE2L2 } & $\begin{array}{c}\text { Pearson } \\
\text { Correlation }\end{array}$ & -0.122 & \multirow[t]{2}{*}{ OMA1 } & $\begin{array}{c}\text { Pearson } \\
\text { Correlation }\end{array}$ & 0.110 \\
\hline & Sig. & 0.216 & & Sig. & 0.500 & & Sig. & 0.555 \\
\hline \multirow[t]{2}{*}{ TNF } & $\begin{array}{l}\text { Pearson } \\
\text { Correlation }\end{array}$ & 0.041 & \multirow[t]{2}{*}{ UCP2 } & $\begin{array}{l}\text { Pearson } \\
\text { Correlation }\end{array}$ & 0.153 & \multirow[t]{2}{*}{ OPA1 } & $\begin{array}{l}\text { Pearson } \\
\text { Correlation }\end{array}$ & 0.125 \\
\hline & Sig. & 0.820 & & Sig. & 0.396 & & Sig. & 0.525 \\
\hline \multirow[t]{2}{*}{ PTGS2 } & $\begin{array}{c}\text { Pearson } \\
\text { Correlation }\end{array}$ & -0.200 & SLC25A14 & $\begin{array}{c}\text { Pearson } \\
\text { Correlation }\end{array}$ & -0.163 & * The corr & ion is signific & $p<0.05$ \\
\hline & Sig. & 0.317 & & Sig. & 0.364 & ** The cor & tion is signific & $p<0.01$ \\
\hline & & & & (b) & & & & \\
\hline ESR2 & $\begin{array}{c}\text { Pearson } \\
\text { Correlation }\end{array}$ & 1.000 & CAT & $\begin{array}{c}\text { Pearson } \\
\text { Correlation }\end{array}$ & & & $\begin{array}{c}\text { Pearson } \\
\text { Correlation }\end{array}$ & 0.260 \\
\hline & Sig. & & & Sig. & & & Sig. & 0.220 \\
\hline IL6R & $\begin{array}{c}\text { Pearson } \\
\text { Correlation }\end{array}$ & $0.639^{* *}$ & GPX1 & $\begin{array}{c}\text { Pearson } \\
\text { Correlation }\end{array}$ & & & $\begin{array}{c}\text { Pearson } \\
\text { Correlation }\end{array}$ & $0.483 *$ \\
\hline & Sig. & 0.001 & & Sig. & & & Sig. & 0.017 \\
\hline ESR1 & $\begin{array}{c}\text { Pearson } \\
\text { Correlation }\end{array}$ & 0.010 & GSR & $\begin{array}{c}\text { Pearson } \\
\text { Correlation }\end{array}$ & & & $\begin{array}{c}\text { Pearson } \\
\text { Correlation }\end{array}$ & 0.409 * \\
\hline & Sig. & 0.962 & & Sig. & & & Sig. & 0.047 \\
\hline CXCR8 & $\begin{array}{c}\text { Pearson } \\
\text { Correlation }\end{array}$ & $0.473 *$ & SOD1 & $\begin{array}{c}\text { Pearson } \\
\text { Correlation }\end{array}$ & & & $\begin{array}{c}\text { Pearson } \\
\text { Correlation }\end{array}$ & 0.560 ** \\
\hline & Sig. & 0.023 & & Sig. & & & Sig. & 0.004 \\
\hline IL6 & $\begin{array}{c}\text { Pearson } \\
\text { Correlation }\end{array}$ & -0.060 & SOD2 & $\begin{array}{c}\text { Pearson } \\
\text { Correlation }\end{array}$ & & & $\begin{array}{c}\text { Pearson } \\
\text { Correlation }\end{array}$ & 0.326 \\
\hline & Sig. & 0.781 & & Sig. & & & Sig. & 0.120 \\
\hline CXCL8 & $\begin{array}{c}\text { Pearson } \\
\text { Correlation }\end{array}$ & 0.374 & SIRT3 & $\begin{array}{c}\text { Pearson } \\
\text { Correlation }\end{array}$ & & & $\begin{array}{c}\text { Pearson } \\
\text { Correlation }\end{array}$ & 0.294 \\
\hline & Sig. & 0.071 & & Sig. & & & Sig. & 0.163 \\
\hline TGFB & $\begin{array}{c}\text { Pearson } \\
\text { Correlation }\end{array}$ & 0.169 & NFE2L2 & $\begin{array}{c}\text { Pearson } \\
\text { Correlation }\end{array}$ & & & $\begin{array}{c}\text { Pearson } \\
\text { Correlation }\end{array}$ & $0.446^{*}$ \\
\hline & Sig. & 0.430 & & Sig. & & & Sig. & 0.029 \\
\hline TNF & $\begin{array}{c}\text { Pearson } \\
\text { Correlation }\end{array}$ & 0.326 & UCP2 & $\begin{array}{c}\text { Pearson } \\
\text { Correlation }\end{array}$ & & & $\begin{array}{c}\text { Pearson } \\
\text { Correlation }\end{array}$ & 0.256 \\
\hline & Sig. & 0.120 & & Sig. & & & Sig. & 0.262 \\
\hline PTGS2 & $\begin{array}{c}\text { Pearson } \\
\text { Correlation }\end{array}$ & -0.155 & SLC25A14 & $\begin{array}{l}\text { Pearson } \\
\text { Correlation }\end{array}$ & & correlation is si & ficant at $p<0$. & \\
\hline & Sig. & 0.502 & & Sig. & & correlation is s & ficant at $p<0$ & \\
\hline
\end{tabular}




\section{Discussion}

In this study, the effects of obesity related-inflammation on mitochondrial functionality in breast cancer cell lines and breast tumors, focusing on estrogen receptors ratio, were analyzed. Moreover, invasiveness in this situation was also analyzed. We demonstrated that ER $\beta$, in an inflammatory and obesity condition, maintains mitochondrial functionality and avoids invasiveness in breast cancer cell lines. Moreover, we found a strong correlation between interleukin- 6 receptor gene expression and inflammation, mitochondrial functionality, and oxidative stress markers, as well as with estrogen receptor beta, in breast cancer human samples in different BMI situations.

Obesity stimulates the adipose tissues to release inflammatory mediators such as tumor necrosis factor $\alpha$ and interleukin 6 , predisposing them to a proinflammatory state and oxidative stress $[14,39]$. These signals also stimulate the release of inflammatory mediators by breast cancer cells, creating an autocrine feedback loop [40]. To start the study, we confirmed the effects of treatment on inflammatory genes expression. ELIT treatment (17ß-estradiol $(10 \mathrm{nM})$, Leptin $(100 \mathrm{ng} / \mathrm{mL})$, IL6 $(50 \mathrm{ng} / \mathrm{mL})$, and TNF $\alpha(10 \mathrm{ng} / \mathrm{mL})$ ), simulates circulating hormonal conditions in a postmenopausal obese woman and inducing a high increase in proinflammatory expression genes. Furthermore, it is worth noting that, in breast tumors in different BMI situations, inflammatory genes expression was positively correlated with interleukin-6 receptor gene expression. These results are in concordance with other studies where proinflammatory markers are studied in postmenopausal breast cancer patients [32].

Previous studies in our group and other research groups have shown the independent effects of $17 \beta$-estradiol or leptin on oxidative stress and mitochondrial biogenesis and dynamics [9,41-44], but never in an associated-inflammation situation. It is well known that ER $\alpha$ is the predominant estrogen receptor found in the MCF7 cell line, and it responds to estrogens by increasing proliferation, while, if ER $\beta$ is overexpressed in these cells, the proliferative effect of estrogens is inhibited [9]. Therefore, the response to estrogens in breast cancer not only depends on the concentration of estrogens in the cellular environment but also depends on the $E R \alpha / E R \beta$ ratio presented by cells $[9,43]$.

In this study, MCF7 and T47D cell lines have been treated with an ELIT inflammatory cocktail with the aim of generates an inflammation situation (IL6 and TNF $\alpha$ ) in the presence of Leptin and $17 \beta$-estradiol levels, simulating the physiological condition of postmenopausal obese women. In this way, an increase in reactive oxygen species has been observed in both cell lines; however, in the T47D cell line, a lower increase in the production of hydrogen peroxide and levels of superoxide anion was observed. These data make more sense when studying the oxidative damage present in both cell lines, where a significant increase was only observed in the MCF7 cell line. On the other hand, it seems that the T47D treated cell line does not present differences compared to the control group, despite presenting higher levels of $\mathrm{H}_{2} \mathrm{O}_{2}$ and superoxide anion, as similarly described by some authors $[41,45,46]$.

Oxidative stress is generated in breast cancer, and in many other pathologies, in two main ways. The first one, as observed in the high ER $\alpha / E R \beta$ ratio MCF7 cell line after ELIt treatment, is a decrease in the expression of the antioxidant enzymes. It was observed that all antioxidant enzymes had decreased their gene or protein expression in the MCF7 cell line, except the SOD2 enzyme that had increased expression in both MCF7 and T47D cell lines. It has been described that SOD2 plays a role as a free radical detector, increasing gene and/or protein expression in order to alleviate oxidative damage [47]. Moreover, NFE2L2, a transcription factor that controls mainly antioxidant enzymes expression, and glutathione reductase, which recycles glutathione, was also increased, avoiding a high increase in free radical levels in low ER $\alpha / E R \beta$ ratio T47D cell line. In addition, it should be noted that those tumors with a high correlation between IL6R and ESR2 gene expression presented an increase in antioxidant enzymes, thus could palliate levels of free radicals, which can ultimately diminish oxidative damage. 
The other pathway that increases oxidative stress is the poor maintenance of a functional mitochondrial pool [48]. To achieve good maintenance, two highly coordinated processes, such as mitochondrial biogenesis and dynamics, are very important $[49,50]$. In the MCF7 cell line, where ER $\alpha$ predominates, the protein levels of the OXPHOS system are decreased after ELIT treatment, as well as the amount of inner mitochondrial membrane (cardiolipin levels), required for the activity of complexes I, III, and IV, and plays an important role in mitochondrial biogenesis [51,52]. Likewise, both mitochondrial biogenesis and mitochondrial dynamics are diminished by ELIT treatment in the MCF7 cell line. Therefore, neither mitochondria are generated, nor are those that do not function properly eliminated; thus, the production of free radicals and, consequently, the oxidative damage is increased. Mitochondrial dysfunction has been postulated as one of the hallmarks of cancer, increasing free radicals and decrease energetic efficiency [19]. If this situation is accompanied by low levels of antioxidant enzymes, oxidative damage will be higher, as observed in the MCF7 cell line.

However, the T47D cell line, with high levels of ER $\beta$, had mitochondrial dynamics elevated, maintaining a more functional pool of mitochondria. In the case of mitochondrial biogenesis, it should be noted that there are two genes that presented a very significant elevation, estrogen-related receptor alpha (ESRRA) and Twinkle (TWNK). ESRRA belongs to a superfamily of nuclear receptors independent of estrogen activation. Its expression is induced and activated by PGC $1 \alpha$, and the two factors together are capable of binding to response elements and promoting the initiation and elongation of the transcription of metabolic and mitochondrial target genes [53]. Twinkle is the mitochondrial helicase encoded by nuclear DNA that acts during mtDNA replication, and its overexpression has been shown to be related to increased mitochondrial biogenesis [54]. In fact, ESRRA should be considered as a possible factor responsible for the difference in the rate of mitochondrial biogenesis between both MCF7 and T47D cell lines in an obese-related inflammation situation. As shown in the results, the increased expression of the nuclear receptor ESRRA in the T47D cell line could be responsible for the maintenance of the mitochondrial pool in the cell. Furthermore, it has been observed that the STAT3 signaling pathway, activated by leptin and IL6, upregulates the expression of ESRRA [55].

Taking into account that patients with tumors with low $E R \alpha / E R \beta$ ratios have a worse response to chemical agents oxidative damage inductors [56], we observed that breast tumors with a high correlation between IL6R and ESR2 in obese patients had genes related to mitochondrial biogenesis, and dynamics increased gene expression, which could be an attempt to increase the number of mitochondria due to the inflammatory state and oxidative stress generated over a long period of time, such happens in other situations like aging [57,58], but maintaining a functional mitochondrial pool. In addition, it is worthy to note that both interleukin 6 and 8 gene expression correlated negatively with estrogen receptor alpha gene expression, whereas both interleukin 6 and 8 receptors correlated positively with estrogen receptor beta gene expression. These results remark the importance of more studies are needed in order to better understand estrogen receptors subtypes' role in breast cancer.

In addition to mitochondrial biogenesis and dynamics, our study reveals an oxygen consumption rate decreased in the MCF7 cell line that supports all the results commented above. It is worth noting that ELIT treatment decreases basal respiration, maximal respiratory capacity, ATP-linked respiration as much as proton leak in the MCF7 cell line. Proton leak decrease is in concordance with low uncoupling proteins mRNA expression levels found in the MCF7 cell line after ELIT treatment. UCPs, which promote proton leak across the inner mitochondrial membrane, have emerged as essential regulators of mitochondrial membrane potential, respiratory activity, and ROS generation [59]. As seen in our results, the mitochondrial network was modified in the MCF7 cell line after treatment. Mitochondria appear more fragmented and circular than fused in the ELIT-treated MCF7 cell line but not in the T47D cell line. In fact, it seems that estrogen receptor beta could maintain mitochondrial network as well as oxygen consumption rate. Moreover, the T47D 
cell line showed an increase in the reserve capacity of mitochondria, a fact that supports good mitochondrial pool maintenance $[48,60,61]$.

Oxidative stress, inflammation, and poor mitochondrial network observed in MCF7 cell lines after ELIT treatment leads to a worse situation, and some authors have described a relationship between this situation and metastasis [62]. Our results are in concordance with this idea due to increased motility and modification of invasiveness markers presented in the MCF7 cell line but not in the T47D cell line after treatment. In fact, the T47D cell line, with a better mitochondrial profile, including biogenesis, dynamics, and mitochondrial network, showed high levels of Cadherin-E that could simulate an epithelial-like phenotype, as suggested by some authors $[63,64]$.

As mentioned above, the MCF7 cell line has a higher ER $\alpha / E R \beta$ ratio, and the T47D cell line has a lower ratio. ELIT-treatment decreases estrogen receptor alpha mRNA expression in both MCF7 and T47D cell lines, as shown in results. However, estrogen receptor beta mRNA expression only decreases in the MCF7 cell line but not in the T47D cell line. This fact supports that all the results showed in our study could be through estrogen receptor beta T47D cell lines maintenance, giving to this receptor subtype the protective role that previously some studies have been described $[9,39]$.

\section{Conclusions}

The presence of estrogen receptor beta allows maintaining a more functional mitochondrial pool, with active mitochondrial biogenesis and dynamics, which means less production of reactive oxygen species and better mitochondrial metabolism in an obesityrelated inflammation condition. In addition, antioxidant enzymes are active, preventing oxidative damage and, at least in part, invasiveness.

This study could be important to remark the importance of estrogen receptor beta and mitochondria as an important organelle in the development and prognosis of breast cancer in obese patients. Likewise, more studies are necessary in order to clarify the estrogen receptor beta mechanism in breast cancer and establish it as a clinical biomarker, as is the estrogen receptor alpha.

Supplementary Materials: The following are available online at https://www.mdpi.com/article/ 10.3390/antiox10091371/s1, Figure S1: Representative bands and values of Inmunoblotting against GAPDH (approximately $37 \mathrm{kDa}$ ). Order of wells and Relative intensity values are above the blot image, control situation of each cell line set as 100; Figure S2: Representative bands and values of Inmunoblotting against 4HNE. Order of wells and Relative intensity values are above the blot image, control situation of each cell line set as 100; Figure S3: Representative bands and values of Inmunoblotting against SOD1 (Approximately $16 \mathrm{kDa}$ ). Order of wells and Relative intensity values are above the blot image, control situation of each cell line set as 100; Figure S4: Representative bands and values of Inmunoblotting against SOD2 (Approximately $25 \mathrm{kDa}$ ). Order of wells and Relative intensity values are above the blot image, control situation of each cell line set as 100; Figure S5: Representative bands and values of Inmunoblotting against GRd (Approximately $56 \mathrm{kDa}$ ). Order of wells and Relative intensity values are above the blot image, control situation of each cell line set as 100; Figure S6: Representative bands and values of Inmunoblotting against CAT (Approximately $60 \mathrm{kDa}$ ). Order of wells and Relative intensity values are above the blot image, control situation of each cell line set as 100; Figure S7: Representative bands and values of Inmunoblotting against OXPHOS (Cocktail antibody was used). Order of wells are above the blot image and Relative intensity values in table, control situation of each cell line set as 100; Figure S8: Representative bands and values of Inmunoblotting against COXIV; Figure S9: Illustrations of Wound Healing in both MCF7 and T47D cell lines after 0,12 and $24 \mathrm{~h}$ of ELIT treatment.

Author Contributions: Conceptualization: D.G.P., J.O., P.R. and J.S.-S.; Methodology: T.M.-B., N.C. and J.S.-S.; Validation: D.G.P., T.M.-B., N.C., J.O., P.R. and J.S.-S.; Formal Analysis: D.G.P., J.O., P.R., T.M.-B. and J.S.-S.; Investigation: J.S.-S., D.G.P., T.M.-B. and P.R.; Data Curation: D.G.P., J.O., P.R., T.M.-B. and J.S.-S.; Writing-Original Draft Preparation: T.M.-B. and J.S.-S.; Writing-Review and Editing: D.G.P., J.O., P.R., T.M.-B. and J.S.-S.; Supervision: P.R. and J.S.-S.; Project Administration: 
D.G.P., J.O., P.R. and J.S.-S.; Funding Acquisition: J.S.-S. and P.R. All authors have read and agreed to the published version of the manuscript.

Funding: This research was funded by PRIMUS program from the Balearic Islands Health Research Institute (IdISBa), grant number "PRI18/04", and the Fundraising Project: Proyecto Investigación en Cáncer de Mama (InCaM), Fundació Universitat Empresa de les Illes Balears (FUEIB)—Oficina de Fundraising. Feim Camí per Viure-Santa Maria del Camí. T. Martinez-Bernabe was funded by "Ayuda Formación Personal Investigador FPI 2020" grant from “Consejería de Educación, Universidad e Investigación del Gobierno de las Illes Balears".

Institutional Review Board Statement: The study was conducted according to the guidelines of the Declaration of Helsinki and approved by the "Comité de ética de la Investigación de las Islas Baleares (IB3888/18 PI, 10 June 2019).

Informed Consent Statement: Informed consent was obtained from all subjects involved in the study. Written informed consent has been obtained from the patient(s) to publish this paper.

Data Availability Statement: Data is contained within the article and Supplementary Materials.

Acknowledgments: We thank Laura Puigrós for her technician work inside "SOIB-Joves Qualificats" program. The authors thank Guillem Ramis from the coelomic unit (IUNICS-UIB) for assistance and the acquisition of the confocal microscopy images. This work was published thanks to funding from "LIBERI 2021" program from the Balearic Islands Health Research Institute (IdISBa).

Conflicts of Interest: The authors declare no conflict of interest.

\section{References}

1. Harbeck, N.; Penault-Llorca, F.; Cortés, J.; Gnant, M.; Houssami, N.; Poortmans, P.; Ruddy, K.; Tsang, J.; Cardoso, F. Breast cancer. Nat. Rev. Dis. Primers 2019, 5, 66. [CrossRef]

2. Tao, Z.Q.; Shi, A.; Lu, C.; Song, T.; Zhang, Z.; Zhao, J. Breast Cancer: Epidemiology and Etiology. Cell Biochem. Biophys. 2015, 72, 333-338. [CrossRef]

3. Calle, E.E.; Kaaks, R. Overweight, obesity and cancer: Epidemiological evidence and proposed mechanisms. Nat. Rev. Cancer 2004, 4, 579-591. [CrossRef]

4. KA, B. Metabolic pathways in obesity-related breast cancer. Nat. Rev. Endocrinol. 2021, 17, 350-363. [CrossRef]

5. Himbert, C.; Delphan, M.; Scherer, D.; Bowers, L.W.; Hursting, S.; Ulrich, C.M. Signals from the Adipose Microenvironment and the Obesity-Cancer Link-A Systematic Review. Cancer Prev. Res. 2017, 10, 494. [CrossRef] [PubMed]

6. Klinge, C.M. Estrogenic control of mitochondrial function. Redox Biol. 2020, 31, 101435. [CrossRef]

7. Roberts, D.L.; Dive, C.; Renehan, A.G. Biological mechanisms linking obesity and cancer risk: New perspectives. Annu. Rev. Med. 2010, 61, 301-316. [CrossRef] [PubMed]

8. Liao, T.L.; Tzeng, C.R.; Yu, C.L.; Wang, Y.P.; Kao, S.H. Estrogen receptor- $\beta$ in mitochondria: Implications for mitochondrial bioenergetics and tumorigenesis. Ann. N. Y. Acad. Sci. 2015, 1350, 52-60. [CrossRef] [PubMed]

9. Sastre-Serra, J.; Nadal-Serrano, M.; Pons, D.G.; Roca, P.; Oliver, J. The over-expression of ERbeta modifies estradiol effects on mitochondrial dynamics in breast cancer cell line. Int. J. Biochem. Cell Biol. 2013, 45, 1509-1515. [CrossRef] [PubMed]

10. Simone, V.; D’Avenia, M.; Argentiero, A.; Felici, C.; Rizzo, F.M.; De Pergola, G.; Silvestris, F. Obesity and Breast Cancer: Molecular Interconnections and Potential Clinical Applications. Oncologist 2016, 21, 404. [CrossRef]

11. Shouman, S.; Wagih, M.; Kamel, M. Leptin influences estrogen metabolism and increases DNA adduct formation in breast cancer cells. Cancer Biol. Med. 2016, 13, 505. [CrossRef]

12. Postow, M.A.; Callahan, M.K.; Wolchok, J.D. Immune checkpoint blockade in cancer therapy. J. Clin. Oncol. 2015, 33, 1974-1982. [CrossRef] [PubMed]

13. Zhou, X.; Yang, S.; Wang, Z.; Feng, X.; Liu, P.; Lv, X.-B.; Li, F.; Yu, F.-X.; Sun, Y.; Yuan, H.; et al. Estrogen regulates Hippo signaling via GPER in breast cancer. J. Clin. Investig. 2015, 125, 2123-2135. [CrossRef] [PubMed]

14. Macciò, A.; Madeddu, C. Obesity, inflammation, and postmenopausal breast cancer: Therapeutic implications. Sci. World J. 2011, 11, 2020-2036. [CrossRef] [PubMed]

15. Bhat, H.K.; Calaf, G.; Hei, T.K.; Loya, T.; Vadgama, J.V. Critical role of oxidative stress in estrogen-induced carcinogenesis. Proc. Natl. Acad. Sci. USA 2003, 100, 3913-3918. [CrossRef]

16. Goldberg, J.E.; Schwertfeger, K.L. Proinflammatory Cytokines in Breast Cancer: Mechanisms of Action and Potential Targets for Therapeutics. Curr. Drug Targets 2010, 11, 1133-1146. [CrossRef]

17. Choi, J.; Cha, Y.J.; Koo, J.S. Adipocyte biology in breast cancer: From silent bystander to active facilitator. Prog. Lipid Res. 2018, 69, 11-20. [CrossRef]

18. Crusz, S.M.; Balkwill, F.R. Inflammation and cancer: Advances and new agents. Nat. Rev. Clin. Oncol. 2015, 12, 584-596. [CrossRef]

19. Hanahan, D.; Weinberg, R.A. Hallmarks of cancer: The next generation. Cell 2011, 144, 646-674. [CrossRef] 
20. Pedram, A.; Razandi, M.; Wallace, D.C.; Levin, E.R. Functional estrogen receptors in the mitochondria of breast cancer cells. Mol. Biol. Cell 2006, 17, 2125-2137. [CrossRef]

21. Fariss, M.W.; Chan, C.B.; Patel, M.; Van Houten, B.; Orrenius, S. Role of mitochondria in toxic oxidative stress. Mol. Interv. 2005, 5, 94-111. [CrossRef]

22. Murphy, M.P. How mitochondria produce reactive oxygen species. Biochem. J. 2009, 417, 1-13. [CrossRef]

23. Moloney, J.N.; Cotter, T.G. ROS signalling in the biology of cancer. Semin. Cell Dev. Biol. 2018, 80, 50-64. [CrossRef]

24. Justo, R.; Boada, J.; Frontera, M.; Oliver, J.; Bermúdez, J.; Gianotti, M. Gender dimorphism in rat liver mitochondrial oxidative metabolism and biogenesis. Am. J. Physiol. Physiol. 2005, 289, C372-C378. [CrossRef] [PubMed]

25. Liesa, M.; Palacín, M.; Zorzano, A. Mitochondrial dynamics in mammalian health and disease. Physiol. Rev. 2009, 89, 799-845. [CrossRef] [PubMed]

26. Sastre-Serra, J.; Nadal-Serrano, M.; Pons, D.G.; Valle, A.; Oliver, J.; Roca, P. The effects of $17 \beta$-estradiol on mitochondrial biogenesis and function in breast cancer cell lines are dependent on the ER $\alpha /$ ER $\beta$ Ratio. Cell. Physiol. Biochem. 2012, 29, 261-268. [CrossRef] [PubMed]

27. Guha, M.; Srininvasan, S.; Ruthel, G.; Kashina, A.K.; Carstens, R.P.; Mendoza, A.; Khanna, C.; Van Winkle, T.; Avadhani, N.G. Mitochondrial retrograde signaling induces epithelial-mesenchymal transition and generates breast cancer stem cells. Oncogene 2014, 33, 5238-5250. [CrossRef] [PubMed]

28. Tsai, J.H.; Yang, J. Epithelial-mesenchymal plasticity in carcinoma metastasis. Genes Dev. 2013, 27, 2192-2206. [CrossRef] [PubMed]

29. Avtanski, D.; Garcia, A.; Caraballo, B.; Thangeswaran, P.; Marin, S.; Bianco, J.; Lavi, A.; Poretsky, L. Resistin induces breast cancer cells epithelial to mesenchymal transition (EMT) and stemness through both adenylyl cyclase-associated protein 1 (CAP1)-dependent and CAP1-independent mechanisms. Cytokine 2019, 120, 155-164. [CrossRef]

30. Olea-Flores, M.; Juárez-Cruz, J.C.; Mendoza-Catalán, M.A.; Padilla-Benavides, T.; Navarro-Tito, N. Signaling Pathways Induced by Leptin during Epithelial-Mesenchymal Transition in Breast Cancer. Int. J. Mol. Sci. 2018, 19, 3493. [CrossRef] [PubMed]

31. Valle, A.; Sastre-Serra, J.; Oliver, J.; Roca, P. Chronic leptin treatment sensitizes MCF-7 breast cancer cells to estrogen. Cell. Physiol. Biochem. 2011, 28, 823-832. [CrossRef] [PubMed]

32. Madeddu, C.; Gramignano, G.; Floris, C.; Murenu, G.; Sollai, G.; Macciò, A. Role of inflammation and oxidative stress in post-menopausal oestrogen-dependent breast cancer. J. Cell. Mol. Med. 2014, 18, 2519. [CrossRef] [PubMed]

33. Rose, D.P.; Vona-Davis, L. Biochemical and molecular mechanisms for the association between obesity, chronic Inflammation, and breast cancer. BioFactors 2014, 40,1-12. [CrossRef]

34. Sastre-Serra, J.; Ahmiane, Y.; Roca, P.; Oliver, J.; Pons, D.G. Xanthohumol, a hop-derived prenylflavonoid present in beer, impairs mitochondrial functionality of SW620 colon cancer cells. Int. J. Food Sci. Nutr. 2019, 70, 396-404. [CrossRef] [PubMed]

35. Torrens-Mas, M.; Hernández-López, R.; Pons, D.G.; Roca, P.; Oliver, J.; Sastre-Serra, J. Sirtuin 3 silencing impairs mitochondrial biogenesis and metabolism in colon cancer cells. Am. J. Physiol. Cell Physiol. 2019, 317, C398-C404. [CrossRef]

36. Pons, D.G.; Vilanova-Llompart, J.; Gaya-Bover, A.; Alorda-Clara, M.; Oliver, J.; Roca, P.; Sastre-Serra, J. The phytoestrogen genistein affects inflammatory-related genes expression depending on the ER $\alpha / \mathrm{ER} \beta$ ratio in breast cancer cells. Int. J. Food Sci. Nutr. 2019, 70, 941-949. [CrossRef]

37. Pons, D.G.; Moran, C.; Alorda-Clara, M.; Oliver, J.; Roca, P.; Sastre-Serra, J. Micronutrients Selenomethionine and Selenocysteine Modulate the Redox Status of MCF-7 Breast Cancer Cells. Nutrients 2020, 12, 865. [CrossRef]

38. Nadal-Serrano, M.; Sastre-Serra, J.; Pons, D.G.; Miró, A.M.; Oliver, J.; Roca, P. The ERalpha/ERbeta ratio determines oxidative stress in breast cancer cell lines in response to 17Beta-estradiol. J. Cell. Biochem. 2012, 113, 3178-3182. [CrossRef]

39. Ellulu, M.S.; Patimah, I.; Khazaai, H.; Rahmat, A.; Abed, Y. Obesity \& inflammation: The linking mechanism \& the complications. Arch. Med. Sci. 2017, 13, 851-863. [CrossRef]

40. Hartman, Z.C.; Poage, G.M.; Den Hollander, P.; Tsimelzon, A.; Hill, J.; Panupinthu, N.; Zhang, Y.; Mazumdar, A.; Hilsenbeck, S.G.; Mills, G.B.; et al. Growth of triple-negative breast cancer cells relies upon coordinate autocrine expression of the proinflammatory cytokines IL-6 and IL-8. Cancer Res. 2013, 73, 3470-3480. [CrossRef]

41. Pons, D.G.; Torrens-Mas, M.; Nadal-Serrano, M.; Sastre-Serra, J.; Roca, P.; Oliver, J. The presence of Estrogen Receptor $\beta$ modulates the response of breast cancer cells to therapeutic agents. Int. J. Biochem. Cell Biol. 2015, 66, 85-94. [CrossRef] [PubMed]

42. Sastre-Serra, J.; Valle, A.; Company, M.M.; Garau, I.; Oliver, J.; Roca, P. Estrogen down-regulates uncoupling proteins and increases oxidative stress in breast cancer. Free Radic. Biol. Med. 2010, 48, 506-512. [CrossRef] [PubMed]

43. Morani, A.; Warner, M.; Gustafsson, J.Å. Biological functions and clinical implications of oestrogen receptors alfa and beta in epithelial tissues. J. Intern. Med. 2008, 264, 128-142. [CrossRef] [PubMed]

44. Hartman, J.; Müller, P.; Foster, J.S.; Wimalasena, J.; Gustafsson, J.Å.; Ström, A. HES-1 inhibits 17 $\beta$-estradiol and heregulin- $\beta 1-$ mediated upregulation of E2F-1. Oncogene 2004, 23, 8826-8833. [CrossRef] [PubMed]

45. Torrens-Mas, M.; Pons, D.G.; Sastre-Serra, J.; Oliver, J.; Roca, P. SIRT3 Silencing Sensitizes Breast Cancer Cells to Cytotoxic Treatments Through an Increment in ROS Production. J. Cell. Biochem. 2017, 118, 397-406. [CrossRef]

46. Abboud, M.M.; Al Awaida, W.; Alkhateeb, H.H.; Abu-Ayyad, A.N. Antitumor Action of Amygdalin on Human Breast Cancer Cells by Selective Sensitization to Oxidative Stress. Nutr. Cancer 2019, 71, 483-490. [CrossRef] [PubMed]

47. Hu, Y.; Rosen, D.G.; Zhou, Y.; Feng, L.; Yang, G.; Liu, J.; Huang, P. Mitochondrial manganese-superoxide dismutase expression in ovarian cancer: Role in cell proliferation and response to oxidative stress. J. Biol. Chem. 2005, 280, 39485-39492. [CrossRef] 
48. Perron, N.R.; Beeson, C.; Rohrer, B. Early alterations in mitochondrial reserve capacity; a means to predict subsequent photoreceptor cell death. J. Bioenerg. Biomembr. 2013, 45, 101-109. [CrossRef]

49. Rodrigues, T.; Ferraz, L.S. Therapeutic potential of targeting mitochondrial dynamics in cancer. Biochem. Pharmacol. 2020, 182, 114282. [CrossRef]

50. Blanquer-Rossellõ, M.M.; Santandreu, F.M.; Oliver, J.; Roca, P.; Valle, A. Leptin Modulates Mitochondrial Function, Dynamics and Biogenesis in MCF-7 Cells. J. Cell. Biochem. 2015, 116, 2039-2048. [CrossRef]

51. Genova, M.L.; Lenaz, G. Functional role of mitochondrial respiratory supercomplexes. Biochim. Biophys. Acta BBA Bioenerg. 2014, 1837, 427-443. [CrossRef] [PubMed]

52. Paradies, G.; Paradies, V.; Ruggiero, F.M.; Petrosillo, G. Role of Cardiolipin in Mitochondrial Function and Dynamics in Health and Disease: Molecular and Pharmacological Aspects. Cells 2019, 8, 728. [CrossRef] [PubMed]

53. Sanchis-Gomar, F.; Garcia-Gimenez, J.; Gomez-Cabrera, M.; Pallardo, F. Mitochondrial Biogenesis in Health and Disease. Molecular and Therapeutic Approaches. Curr. Pharm. Des. 2014, 20, 5619-5633. [CrossRef]

54. Ikeda, M.; Ide, T.; Fujino, T.; Arai, S.; Saku, K.; Kakino, T.; Tyynismaa, H.; Yamasaki, T.; Yamada, K.I.; Kang, D.; et al. Overexpression of TFAM or twinkle increases mtDNA copy number and facilitates cardioprotection associated with limited mitochondrial oxidative stress. PLoS ONE 2015, 10, e0119687. [CrossRef] [PubMed]

55. Ma, J.H.; Qi, J.; Lin, S.Q.; Zhang, C.Y.; Liu, F.Y.; Xie, W.D.; Li, X. STAT3 targets ERR- $\alpha$ to promote epithelial-mesenchymal transition, migration, and invasion in triple-negative breast cancer cells. Mol. Cancer Res. 2019, 17, 2184-2195. [CrossRef]

56. Sastre-Serra, J.; Nadal-Serrano, M.; Pons, D.G.; Valle, A.; Garau, I.; García-Bonafé, M.; Oliver, J.; Roca, P. The oxidative stress in breast tumors of postmenopausal women is ER $\alpha / \mathrm{ER} \beta$ ratio dependent. Free Radic. Biol. Med. 2013, 61, 11-17. [CrossRef]

57. Guevara, R.; Santandreu, F.M.; Valle, A.; Gianotti, M.; Oliver, J.; Roca, P. Sex-dependent differences in aged rat brain mitochondrial function and oxidative stress. Free Radic. Biol. Med. 2009, 46, 169-175. [CrossRef]

58. Valle, A.; Guevara, R.; García-Palmer, F.J.; Roca, P.; Oliver, J. Caloric restriction retards the age-related decline in mitochondrial function of brown adipose tissue. Rejuvenation Res. 2008, 11, 597-604. [CrossRef]

59. Akhmedov, A.T.; Rybin, V.; Marín-García, J. Mitochondrial oxidative metabolism and uncoupling proteins in the failing heart. Hear. Fail. Rev. 2014, 20, 227-249. [CrossRef]

60. Rambold, A.S.; Kostelecky, B.; Lippincott-Schwartz, J. Together we are stronger: Fusion protects mitochondria from autophagosomal degradation. Autophagy 2011, 7, 1568. [CrossRef]

61. Rambold, A.S.; Kostelecky, B.; Elia, N.; Lippincott-Schwartz, J. Tubular network formation protects mitochondria from autophagosomal degradation during nutrient starvation. Proc. Natl. Acad. Sci. USA 2011, 108, 10190. [CrossRef] [PubMed]

62. Pani, G.; Galeotti, T.; Chiarugi, P. Metastasis: Cancer cell's escape from oxidative stress. Cancer Metastasis Rev. 2010, 29, 351-378. [CrossRef] [PubMed]

63. Adams, B.D.; Claffey, K.P.; White, B.A. Argonaute-2 Expression Is Regulated by Epidermal Growth Factor Receptor and MitogenActivated Protein Kinase Signaling and Correlates with a Transformed Phenotype in Breast Cancer Cells. Endocrinology 2009, 150, 14. [CrossRef] [PubMed]

64. Wang, Y.Y.; Attané, C.; Milhas, D.; Dirat, B.; Dauvillier, S.; Guerard, A.; Gilhodes, J.; Lazar, I.; Alet, N.; Laurent, V.; et al. Mammary adipocytes stimulate breast cancer invasion through metabolic remodeling of tumor cells. JCI Insight 2017, 2. [CrossRef] [PubMed] 